\title{
Characterization of the pharmacological effects of digitoxin on lung epithelial cells
}

Hosam Abdelmonaim Elbaz

West Virginia University

Follow this and additional works at: https://researchrepository.wvu.edu/etd

\section{Recommended Citation}

Elbaz, Hosam Abdelmonaim, "Characterization of the pharmacological effects of digitoxin on lung epithelial cells" (2011). Graduate Theses, Dissertations, and Problem Reports. 3423.

https://researchrepository.wvu.edu/etd/3423

This Dissertation is protected by copyright and/or related rights. It has been brought to you by the The Research Repository @ WVU with permission from the rights-holder(s). You are free to use this Dissertation in any way that is permitted by the copyright and related rights legislation that applies to your use. For other uses you must obtain permission from the rights-holder(s) directly, unless additional rights are indicated by a Creative Commons license in the record and/ or on the work itself. This Dissertation has been accepted for inclusion in WVU Graduate Theses, Dissertations, and Problem Reports collection by an authorized administrator of The Research Repository @ WVU.

For more information, please contact researchrepository@mail.wvu.edu. 


\title{
CHARACTERIZATION OF THE PHARMACOLOGICAL EFFECTS OF DIGITOXIN ON LUNG EPITHELIAL CELLS
}

\author{
by \\ Hosam Abdelmonaim Elbaz \\ Dissertation submitted to the School of Pharmacy \\ at West Virginia University \\ in partial fulfillment of the requirements \\ for the degree of \\ Doctor of Philosophy \\ in \\ Pharmaceutical and Pharmacological Sciences
}

\author{
Approved by \\ Cerasela Zoica Dinu, Committee Chairperson \\ Yon Rojanasakul \\ Patrick Callery \\ Rae Matsumoto \\ Linda Vona-Davis \\ Basic Pharmaceutical Sciences \\ Morgantown, West Virginia \\ 2011
}

Keywords: Digitoxin, D6-MA analog, cytotoxicity, sub-therapeutic concentrations, anticancer drugs 


\section{ABSTRACT \\ CHARACTERIZATION OF THE PHARMACOLOGICAL EFFECTS OF CARDIAC GLYCOSIDES ON LUNG EPITHELIAL CELLS}

\section{by Hosam Abdelmonaim Elbaz}

Lung diseases (excluding cancer) account for $9 \%$ of all disease related mortalities while lung cancer accounts for $30 \%$ of cancer related mortalities. Therapeutic maneuvers, as surgery are usually unfeasible given the extreme vitality of the lung. Developing novel therapeutic alternatives for lung cancer requires a thorough understanding on the lung epithelial cell behavior following exposure to drugs. The goal of this dissertation was to examine how molecular and cellular characteristics, such as morphology and cell viability, of lung cancer cells will be altered upon exposure to digitoxin, a cardiac glycosides (CGs) and a digitoxin synthetic analog. CGs are a large family of chemical compounds found in several plants and animal species and have been applied for treating congestive heart failure, cardiac arrhythmias, and atrial fibrillation. The study was conducted on non-small cell lung cancer (NSCLC) cells using several techniques such as different cell proliferation assays, fluorescence microscopy, flow cytometry, western blotting, and confocal microscopy. 


\section{DEDICATION}

My Parents Abdelmonaim Elbaz and Ibtesam Abdelhameed

My wife Omayma Alshaarawy

My daughter Hannah and son Omar

My brother Moataz Elbaz and sister Gehan Elbaz 


\section{ACKNOWLEDGMENTS}

The process of conducting research is unfeasible without the personal and practical support of numerous people. I owe debt of gratitude to all those people who have made this dissertation possible and because of whom my graduate experience has been an enriching and rewarding one.

I am deeply indebted to my esteemed advisor, Dr. Cerasela Zoica Dinu for her encouragement, support, patience and guidance. She is an excellent scientist and mentor, and one of the most efficient persons I have ever encountered. I believe that I am quite fortunate to have had the opportunity to work with her. I also want to thank my co-advisor Dr. Yon Rojanasakul for he has taught me a lot in scientific research, and in life. I am eternally grateful to him for his assistance, guidance, and giving me the opportunity to perform laboratory experiments. I was lucky to have the opportunity to work with both distinguished investigators. Their mentorship provided a well-rounded experience, and they encouraged me to grow as an experimentalist and an independent thinker.

I would also like to thank my committee members, Dr. Patrick Callery, Dr. Linda Vona-Davis, and Dr. Rae Matsumoto for their insightful comments and valuable suggestions that helped in my research. I want to express my deep appreciation and gratitude to Dr. Todd Stueckle for advising me on my research. I thank Dr. George O'Doherty for his collaboration that contributed an important part of my research project.

I would also like to thank the faculty, staff and graduate students of the department of Basic Pharmaceutical Sciences for their help and discussion. I want to acknowledge 
past and current members of Dr. Dinu's lab and Dr. Rojanasakul's lab for being excellent colleagues. I am also grateful to my colleagues at National Institute for Occupational Safety and Health for their assistance and encouragement.

My family has helped me stay sane through these difficult years. Their support and care helped me overcome setbacks and stay focused on my graduate study. I greatly value their kinship and I deeply appreciate their belief in me. 


\section{TABLE OF CONTENTS}

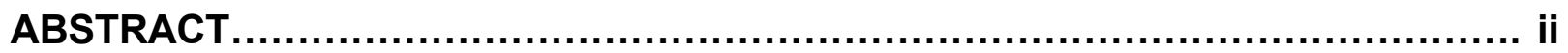

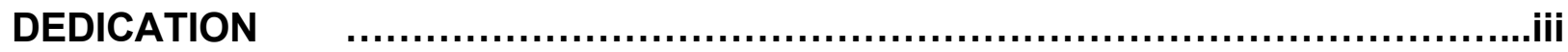

ACKNOWLEDGMENTS......................................................................

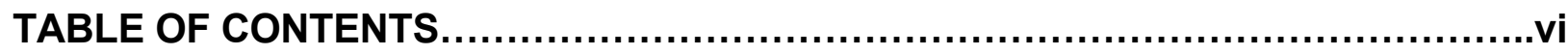

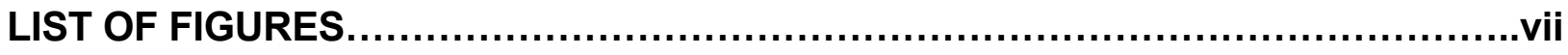

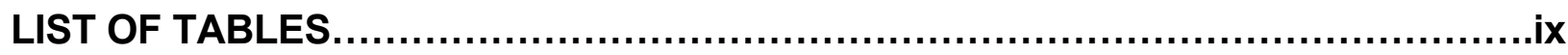

LIST OF SYMBOLS / NOMENCLATURE.......................................................

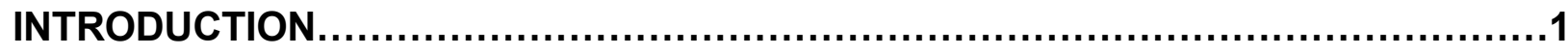

CHAPTER 1: DIGITOXIN, A CARDIAC GLYCOSIDE WITH THE POTENTIAL TO

PROVIDE A NEW HOPE FOR CANCER THERAPY ........................................

CHAPTER 2: DIGITOXIN AND A SYNTHETIC MONOSACCHARIDE ANALOG INHIBIT

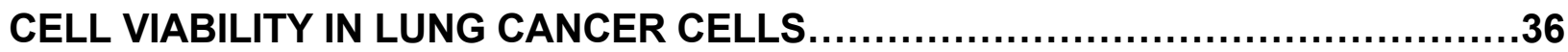

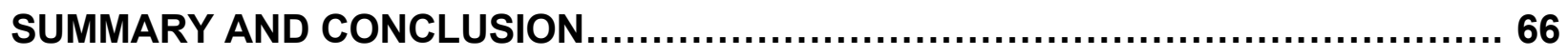

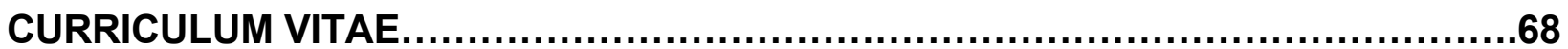




\section{LIST OF FIGURES}

\section{CHAPTER 1: DIGITOXIN, A CARDIAC GLYCOSIDE WITH THE POTENTIAL TO PROVIDE A NEW HOPE FOR CANCER THERAPY}

SCHEME 1: Structural characteristics of CGs.

SCHEME 2: The effects of digitoxin on the $\mathrm{Na}^{+} / \mathrm{K}^{+}$ATPase at micromolar and at nanomolar concentrations. 14

SCHEME 3: The structure of the novel digitoxin analogs. 15

FIGURE 1: Digitoxin manipulates the $\mathrm{Na}^{+} / \mathrm{K}^{+} \mathrm{ATPase}$ signalosome and inhibits the transcriptional activity of AP-1 and NF-KB. 19

\section{CHAPTER 2: DIGITOXIN AND A SYNTHETIC MONOSACCHARIDE ANALOG INHIBIT CELL VIABILITY IN LUNG CANCER CELLS}

FIGURE 1: Digitoxin and D6-MA inhibit $\mathrm{NCl}-\mathrm{H} 460$ cell viability in a dose dependent manner. 46

FIGURE 2: Digitoxin and D6-MA induce $\mathrm{NCl}-\mathrm{H} 460$ cell apoptosis in a dose dependent manner.

FIGURE 3: The apoptotic effect of digitoxin and D6-MA is selective to non-small cell lung cancer cells.

FIGURE 4: Western blot analysis show changes in caspase9, 8 , and 3. .50

FIGURE 5: Western blot analysis shows changes in cytochrome c expression. .51

FIGURE 6: Digitoxin and D6-MA induce G2/M arrest in NCl-H460 cells. .52 
FIGURE 7: Western blot analysis show decreased expression of cyclinB1, cdc2, and

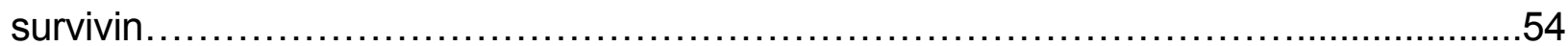

FIGURE 8: Western blot analysis show decreased expression of p53, p21, and p27

FIGURE 9: Western blot analysis show decreased expression of Chk1 and

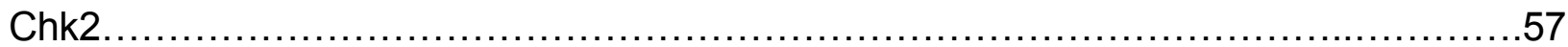




\section{LIST OF TABLES}

CHAPTER 1: DIGITOXIN, A CARDIAC GLYCOSIDE WITH THE POTENTIAL TO PROVIDE A NEW HOPE FOR CANCER THERAPY

\section{TABLE 1:}

A summary of the most studied CGs and their anticancer activity. 


\section{LIST OF SYMBOLS / NOMENCLATURE}

1. AP-1: Activator protein 1

2. Cdc2: cell division cycle 2

3. Cdk1: cyclin dependent kinase 1

4. Cdk4: cyclin dependent kinase 4

5. Chk1: checkpoint kinase protein 1

6. Chk2: checkpoint kinase protein 2

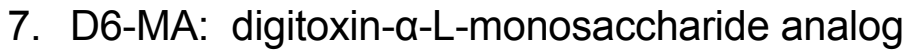

8. MAPK: mitogen activated protein kinase

9. $\mathrm{Na}^{+} / \mathrm{K}^{+}$ATPase: sodium potassium ATPase

10. $\mathrm{Na}^{+} / \mathrm{Ca}^{2+}$ exchanger: sodium calcium exchanger

11. NF-kB: nuclear factor kappa beta

12. NSCLC: non-small cell lung cancer

13. PI3K: phosphatidal inositol-3 kinase

14.PKC: protein kinase $C$

15. PLC: phospholipase C 


\section{INTRODUCTION}

Lungs are extremely vital organs in the living mammalian body. Significantly undermined lung functions are correlated with acute morbidity and mortality. According to the disease statistics conducted by the National Heart Lung and Blood Institute (NHLBI) in 2006, excluding lung cancer, death causes due to lung diseases comprise $9 \%$, while lung cancer accounted for $12.5 \%$ of all new cancer cases and $29 \%$ of all cancer related deaths, ranking second in new cancer cases and first in cancer related mortality [1].

Lung cancer is primarily due to exposure to external or environmental factors, such as smoking, gas radon, and asbestos [2, 3]. Lung cancer has significantly poor prognosis, with a median survival rate of $15 \%$ over a 5 -year period [4]. That is in part due to the wide signaling array that enables lung cancer cells to escape cell death by conventional chemotherapy $[5,6]$, and the limited therapeutic approaches that are able to effectively manage lung cancer $[4,7,8]$. Radiotherapy and/or surgical intervention are usually unfeasible for the majority of lung cancer cases, leaving chemotherapy as one of the few adequate options $[4,7,8]$. Therefore, developing novel therapeutic strategies for lung cancer is of critical need.

Records dating back to the eighth century showed the potential applicability of cardiac glycosides for managing malignant diseases [9, 10]. Later, about two hundred years ago cardiac glycosides were developed as cardiotonic agents [10-12]. Studies on the anti-neoplastic potential for cardiac glycosides continued in the sixties, however they were abandoned due to potential cardiotoxicity of the cardiac glycosides, and lack of representative biological models $[10,13,14]$. Yet, in the late seventies, epidemiological 
studies conducted on breast cancer patients maintained on digitalis (a cardiac glycoside) therapy for cardiac conditions showed that these patients had significantly lower chances for developing malignant conditions, and significantly better prognosis, compared to patients never exposed to digitoxin therapy [15-18].

Laboratory research has also showed that cardiac glycosides possess a promising anti-neoplastic potential against few types of cancer [10, 19-25]. However, the concentrations employed in these studies $(0.1 \mu \mathrm{M}-10 \mu \mathrm{M})[10,26,27]$ significantly exceeded those indicated in the epidemiological reports (15 nM - $40 \mathrm{nM})[15,17,28-30]$. This means that the mechanism by which cardiac glycosides mediate their anti-neoplastic effect at or below therapeutic doses $(15 \mathrm{nM}-40 \mathrm{nM})$ is still unknown.

The work cited above provides convincing evidence that cardiac glycosides can be developed into potential therapeutic strategies to improve the quality of life of persons affected by lung cancer. However, because cardiac glycosides are infamous for cardiotoxicity, they are not actively studied as anticancer therapeutic alternatives $[10,26$, 27, 31]. A potential approach to circumvent their cardiotoxicity is to manipulate their chemical structure.

The long-term goal of this research was to develop cardiac glycosides as novel therapeutic alternatives for lung cancer. In pursuit of this goal, the short-term goal was to examine the effects of digitoxin and a synthetic analog to circumvent digitoxin's cardiotoxicity on $\mathrm{NCl}-\mathrm{H} 460$ cells, a cell model for non-small cell lung cancer (NSCLC) cells. Understanding how digitoxin and synthetic analogue inhibit lung cancer cell viability would provide a broader perspective on how those chemical agents mediate their anti- 
neoplastic effects. Such understanding would also generate a myriad of new opportunities for developing novel anti-neoplastic drugs for lung cancer.

\section{REFERENCES}

1. Jemal A, Murray T, Ward E, Samuels A, Tiwari RC, Ghafoor A, Feuer EJ, Thun MJ: Cancer Statistics, 2005. CA Cancer J Clin 2005, 55(1):10-30.

2. Mzileni O, Sitas F, Steyn K, Carrara H, Bekker P: Lung cancer, tobacco, and environmental factors in the African population of the Northern Province, South Africa. Tobacco Control 1999, 8(4):398-401.

3. Parkin DM, Sasco AJ: Lung cancer: worldwide variation in occurrence and proportion attributable to tobacco use. Lung Cancer 1993, 9(1-6):1-16.

4. Molina JR, Adjei AA, Jett JR: Advances in Chemotherapy of Non-small Cell Lung Cancer. Chest 2006, 130(4):1211-1219.

5. Lee H-Y, Srinivas H, Xia D, Lu Y, Superty R, LaPushin R, Gomez-Manzano C, Gal AM, Walsh GL, Force T et al: Evidence That Phosphatidylinositol 3-Kinaseand Mitogen-activated Protein Kinase Kinase-4/c-Jun NH2-terminal Kinasedependent Pathways Cooperate to Maintain Lung Cancer Cell Survival. Journal of Biological Chemistry 2003, 278(26):23630-23638.

6. Mayo MW, Denlinger CE, Broad RM, Yeung F, Reilly ET, Shi Y, Jones DR: Ineffectiveness of Histone Deacetylase Inhibitors to Induce Apoptosis Involves the Transcriptional Activation of NF-kB through the Akt Pathway. Journal of Biological Chemistry 2003, 278(21):18980-18989. 
7. Shepherd FA, Dancey J, Ramlau R, Mattson K, Gralla R, O'Rourke M, Levitan N, Gressot L, Vincent M, Burkes $\mathrm{R}$ et al: Prospective Randomized Trial of Docetaxel Versus Best Supportive Care in Patients With Non-Small-Cell Lung Cancer Previously Treated With Platinum-Based Chemotherapy. J Clin Oncol 2000, 18(10):2095-2103.

8. Talbot DC: A randomized phase II pharmacokinetic and pharmacodynamic study of indisulam as second-line therapy in patients with advanced nonsmall cell lung cancer. Clin Cancer Res 2007, 13:1816-1822.

9. Brewer H: Historical perspectives on health. The Journal of the Royal Society for the Promotion of Health 2004, 124(4):184-187.

10. Newman RA, Yang P, Pawlus AD, Block KI: Cardiac Glycosides as Novel Cancer Therapeutic Agents. Molecular Interventions 2008, 8(1):36-49.

11. Rahimtoola SH, Tak T: The use of digitalis in heart failure. Curr Probl Cardiol 1996, 21:781-853.

12. Smith TW: The fundamental mechanism of inotropic action of digitalis. Therapie 1989, 44:431-435.

13. Lopez-Lazaro M: Digitoxin as an anticancer agent with selectivity for cancer cells: possible mechanisms involved. Expert Opin Ther Targets 2007, 11(8):1043-1053.

14. Shiratori O: Growth inhibitory effect of cardiac glycosides and agly cones on neoplastic cells: in vitro and in vivo studies. Gann 1967, 58:521 - 528.

15. Stenkvist B: Cardiac glycosides and breast cancer. Lancet 1979, 1:563. 
16. Stenkvist B: Is digitalis a therapy for breast carcinoma? Oncol Rep 1999, 6:493 $-496$.

17. Stenkvist B: Evidence of a modifying influence of heart glucosides on the development of breast cancer. Anal Quant Cytol 1980, 2:49-54.

18. Stenkvist B, Bengtsson E, Dahlqvist B, Eriksson O, Jarkrans T, Nordin B: Cardiac glycosides and breast cancer, revisited. N Engl J Med 1982, 306:484.

19. Winnicka K, Bielawski K, Bielawska A: Cardiac glycosides in cancer research and cancer therapy. Acta Pol Pharm 2006, 63:109-115.

20. Goldin AG, Safa AR: Digitalis and cancer. Lancet 1984, 1:1134.

21. Prassas I, Diamandis EP: Novel therapeutic applications of cardiac glycosides. Nat Rev Drug Discov 2008, 7(11):926-935.

22. Schoner W: Endogenous cardiac glycosides, a new class of steroid hormones. Eur J Biochem 2002, 269:2440-2448.

23. Schoner W, Scheiner-Bobis G: Endogenous and exogenous cardiac glycosides and their mechanisms of action. Am J Cardiovasc Drugs 2007, 7:173-189.

24. Haux J: Digitoxin is a potential anticancer agent for several types of cancer. Medical Hypotheses 1999, 53(6):543-548.

25. Haux J: Digitalis; impinges on more than just the (ion-) pump. Medical Hypotheses 2002, 59(6):781-782.

26. Prassas I, Diamandis EP: Novel therapeutic applications of cardiac glycosides. Nature reviews Drug discovery 2008, 7(11):926-935. 
27. Winnicka K, Bielawski K, Bielawska A: Cardiac glycosides in cancer research and cancer therapy. Acta Pol Pharm 2006, 63(2):109-115.

28. BøHMER T, RøSETH A: Prolonged digitoxin half-life in very elderly patients. Age Ageing 1998, 27(2):222-224.

29. Stenkvist B: Cardiac glycosides and breast cancer, revisited. $N$ Engl J Med 1982, 306:484.

30. Stenkvist B: Is digitalis a therapy for breast carcinoma? Oncol Rep 1999, 6:493-496.

31. López-Lázaro M: Digitoxin as an anticancer agent with selectivity for cancer cells: possible mechanisms involved. Expert Opin Ther Targets 2007, 11(8):1043-1053. 


\title{
CHAPTER 1
}

\section{DIGITOXIN, A CARDIAC GLYCOSIDE WITH THE POTENTIAL TO PROVIDE A NEW HOPE FOR CANCER THERAPY}

\begin{abstract}
A growing body of evidence indicates that digitoxin cardiac glycoside is a promising anticancer drug when used at therapeutic concentrations. Digitoxin has a prolonged halflife and a well-established clinical profile. New scientific avenues showed that manipulating the chemical structure of the saccharide moiety of the digitoxin leads to synthetic analogs with increased cytotoxic activity. However, the anticancer mechanism of digitoxin or synthetic analogs is still subject to study while concerns about digitoxin's cardiotoxicity precludes its clinical application in cancer therapeutics. This chapter focuses on digitoxin and a digitoxin analog, and their cytotoxic selectivity against cancer cells. Moreover, a new perspective on the pharmacological aspects of digitoxin and its analog is provided to emphasize new directions of study for developing potent chemotherapeutic drugs.
\end{abstract}

\section{INTRODUCTION}

Cardiac glycosides (CGs) are a large family of chemical compounds found in several plants and animal species [1]. Plants containing CGs were used for more than 1500 years as diuretics, emetics, abortifacients, antineoplastics, and heart tonics [2]. In 18th century, English physician and scientist William Withering discovered that a patient with congestive heart failure, "dropsy", improved after administering foxglove extract 
(Digitalis purpurea L.) [3]. Since then, many CGs have been isolated and their pharmacological effects have been tested; subsequently, CGs were used for treating congestive heart failure, cardiac arrhythmias, and atrial fibrillation [4, 5].

Generally, CGs share a common structural motif with a steroidal nucleus, a sugar moiety at position 3 (C3), and a lactone moiety at position 17 (C17) [1]. SCHEME 1 shows the common structural motif of CGs. The steroidal nucleus is the core structure of CG and is considered to be the active pharmacophoric moiety [6]. CGs also show an A/B and $C / D$ cis-conformation that is different from mineralocorticoids, glycocorticoids, or sex hormones known to show trans-confirmation [6]. The presence of sugars at position 3 on the steroid ring significantly modifies the pharmacological profile of each glycoside $[7,8]$. Free aglycones, for instance, show faster and less complex absorption and metabolism compared to their glycosylated counterparts [7]. Additionally, the type of the sugar attached to the steroidal nucleus changes the potency of the CG's compound $[8,9]$.

It is well established that CGs inhibit $\mathrm{Na}^{+} / \mathrm{K}^{+} A T P a s e$ and increases intracellular sodium ions [10]. The $\mathrm{Na}^{+} / \mathrm{K}^{+}$ATPase is a P-type pump that actively transports potassium ions inside and sodium ions outside cells in a 2:3 stoichiometry [11]. Such activity keeps intracellular sodium levels low, thus initiating and sustaining adequate electrochemical gradient across the plasma membrane [11]. Appropriate electrochemical gradient is essential for vital cellular processes such as ion homeostasis, neuronal communication, and apoptosis $[10,12]$. To maintain ion homeostasis after $\mathrm{Na}^{+} / \mathrm{K}^{+} \mathrm{ATPase}$ inhibition by CGs, the cells have to restore intracellular sodium concentration to their basal levels by stimulating the $\mathrm{Na}^{+} / \mathrm{Ca}^{2+}$ exchange pump to extrude sodium ions out of the cell and introduce calcium ions inside the cell [10]. This activity increases intracellular calcium ions 
and results in increased cellular phenomena such as calcium dependent signaling and myocardial contractility [5].

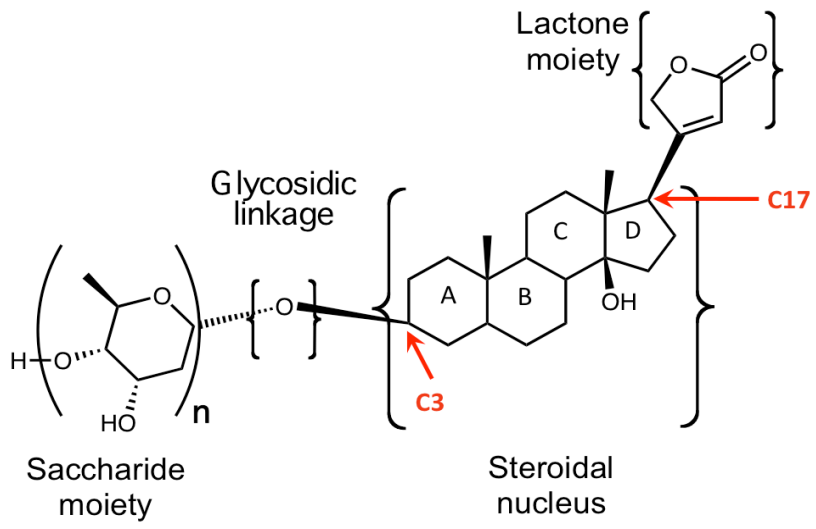

SCHEME 1: Structural characteristics of CGs. The common structural motif of a CG molecule is characterized by a steroidal nucleus, a lactone moiety at $\mathrm{C} 17$, and a saccharide moiety at C3 linked to the steroidal nucleus by a glycosidic linkage.

\section{CARDIAC GLYCOSIDES AND THEIR ANTICANCER POTENTIAL}

A growing body of evidence suggests significant anticancer effects mediated by CGs. For instance, in the 8th century, CG plant extracts were used for treating malignant conditions [13]. An ancient Chinese remedy that employs an extract of Bufo bufo toad secretions contains several CGs and is still being used today for managing cancerous conditions [14-16]. Investigations in using CG's as anticancer drugs intensified in 1960s [17, 18]. Shiratori et al., (1967) examined CGs cytotoxicity on rodent cancer models and found inhibition of in vitro proliferation at concentrations that are relatively toxic to humans $(0.1 \mu \mathrm{M}-10 \mu \mathrm{M})$.

A series of landmark epidemiological studies by Stenkvist et al. compared breast cancer tissue sample from women maintained on digitalis (a CG) for cardiac conditions to 
tissue samples from control patients. This research found that women on digitalis therapy developed more benign forms of breast tumors when compared to control patients [1922]. Additionally, patients on digitalis treatment showed 9.6-times lower cancer recurrence rate compared to control patients after 5 years from mastectomy [21]. In 1984, Goldin and colleagues examined 127 cancer patients treated with digitalis. While patients in the control group had 21 cancer-related deaths, only one patient died in the digitalis group [23]. 20 years later using follow-up data, Stenkvist et al. found that those patients on digitalis treatment showed significantly lower mortality rate compared to the control group [22]. Given the promising epidemiological results and the emergence of human cancer cell lines, several studies investigated the cytotoxic effect of different cardiac glycosides on human cancer cells.

Examples of the cardiac glycosides of plant or animal origins that showed anticancer effects are included in TABLE 1. 
TABLE 1: A summary of the most studied CGs and their anticancer activity.

\begin{tabular}{|c|c|c|c|c|}
\hline Compound & Structure and Natural Origin & Susceptible cancer types & $\mathrm{IC}_{50}(\mu \mathrm{M})$ & References \\
\hline Bufalin & Bufo bufo & $\begin{array}{l}\text { - Prostate cancer (PC3, } \\
\text { DU145, and LNCaP cells) } \\
\text { - Leukemia (THP1, U937, and } \\
\text { MOLT-3 cells) }\end{array}$ & $0.1-10$ & $\begin{array}{l}{[39,40,45-} \\
49]\end{array}$ \\
\hline Cinobufagin & & $\begin{array}{l}\text { Prostate cancer (PC3, } \\
\text { DU145, and LNCaP cells) }\end{array}$ & $0.1-10$ & $\begin{array}{l}{[39,40,45} \\
46,48,49]\end{array}$ \\
\hline Digitoxin & $\begin{array}{l}\text { Digitalis purpurea and Digitalis } \\
\text { lanata, (Scrophulariaceae) }\end{array}$ & $\begin{array}{ll}\text { - } & \text { Prostate cancer (PC3, } \\
\text { DU145, and LNCaP cells) } \\
\text { - } \text { Breast cancer (MCF-7 cells) } \\
\text { - Renal adenocarcinoma (TK- } \\
10 \text { cells) } \\
\text { - } \quad \text { Melanoma (UACC-62 cells) } \\
\text { - Leukemia (K-562 cells) } \\
\text { - Lung (A549 cells, and NCl- } \\
\text { H460 cells) }\end{array}$ & $0.01-10$ & {$[35,50-61]$} \\
\hline Digoxin & $\begin{array}{c}\text { Digitalis purpurea and Digitalis } \\
\text { lanata, (Scrophulariaceae) }\end{array}$ & $\begin{array}{l}\text { Prostate cancer (PC3, } \\
\text { DU145, and LNCaP cells) } \\
\text { - Cervical cancer (Hela cells) } \\
\text { Lung (A549 cells, and NCI- } \\
\text { H460 cells) }\end{array}$ & $0.1-10$ & $\begin{array}{l}{[50-53} \\
61,62]\end{array}$ \\
\hline Oleandrin & $\begin{array}{l}\text { Nerium o } \\
\text { (Apocyr }\end{array}$ & 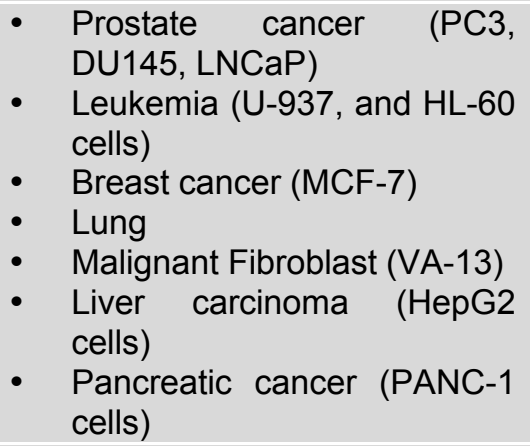 & $0.1-1$ & [63-78] \\
\hline Ouabain & $\begin{array}{l}\text { Strophanth } \\
\text { (Apocyr }\end{array}$ & $\begin{array}{l}\text { Prostate cancer (PC3, } \\
\text { DU145, LNCaP) } \\
\text { Breast cancer (MDA-MB- } \\
\text { 435scells) } \\
\text { - Lung (NCl-H460 cells) }\end{array}$ & $0.1-10$ & $\begin{array}{l}{[10,50,51,} \\
53-56,61,67, \\
79-83]\end{array}$ \\
\hline Proscillaridin & Urginea Maritime & $\begin{array}{l}\text { Breast cancer (MCF-7 } \\
\text { cells) } \\
\text { - Fibroblasts }\end{array}$ & $\begin{array}{l}0.03- \\
0.01\end{array}$ & $\begin{array}{l}{[50,51, \quad 53,} \\
54, \quad 56, \quad 64, \\
84-87]\end{array}$ \\
\hline
\end{tabular}




\section{DIGITOXIN, A WELL ESTABLISHED CARDIAC GLYCOSIDE}

Digitoxin is one of the few CGs that has been extensively studied, and has a wellestablished clinical profile $[24,25]$. Digitoxin is a cardiotonic drug with a narrow therapeutic window; thus, toxicity is a persistent concern whenever digitoxin is considered for therapy [26]. Cardiotoxicity is frequently encountered as the most significant toxicity following digitoxin's clinical administration [27, 28]. However, digitoxin is perhaps the most promising of the CGs since it showed significant anticancer effect against several types of cancer including lung cancer, pancreatic cancer, leukemia, and breast cancer, all at therapeutic concentrations (see TABLE 1) [18, 25, 29-31]. Moreover, digitoxin has a prolonged half-life [26], which can potentially contribute to a less toxic and more stable pharmacokinetic profile in the digitoxin-treated cancer patients. Such advantages qualify digitoxin for further laboratory investigations and clinical trials. However, to justify the anticancer clinical application of digitoxin, its anticancer mechanism is ought to be clearly understood. Also, with the persistent concern about digitoxin's cardiotoxicity, further studies are required to clarify the cytotoxic mechanism of digitoxin in cancer cells.

\section{DIGITOXIN AND ITS ANTICANCER MECHANISM}

To understand its anticancer mechanisms, initial research focused on the ability of digitoxin to inhibit the $\mathrm{Na}^{+} / \mathrm{K}^{+}$ATPase pump at concentrations between $0.5 \mu \mathrm{M}-5 \mu \mathrm{M}[5$, 10-12], [32]. Such inhibition can result in increased intracellular calcium via increased $\mathrm{Na}^{+} / \mathrm{Ca}^{2+}$ pump activity and subsequently induce apoptosis in cancer cells [33-35]. SCHEME $2 \mathrm{~A}$ shows how inhibiting the $\mathrm{Na}^{+} / \mathrm{K}^{+}$ATPase pump will cause accumulation of intracellular sodium, thus perturbation of cellular ion homeostasis [5, 10-12]. For the cells 
to restore ion homeostasis, the $\mathrm{Na}^{+} / \mathrm{Ca}^{2+}$ exchanger need to be activated to export excess sodium to the extracellular space while importing calcium, which in turn causes accumulation of intracellular calcium that mediate events as myocardial contractility, cytoskeleton remodeling, and apoptosis [5, 10-12]. Interestingly, however, epidemiological studies showed that digitoxin inhibits cancer cell viability at nanomolar concentrations (10 nM - $100 \mathrm{nM})[18,30,31,36]$. This suggests that digitoxin exhibits a different mechanism for its anticancer effect than the one initially proposed.

(A)

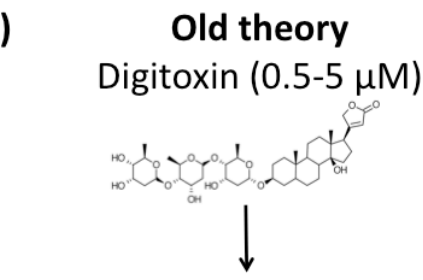

$\mathrm{Na}^{+} / \mathrm{K}^{+}$ATPase inhibition

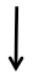

Intracellular $\mathrm{Na}^{+}$

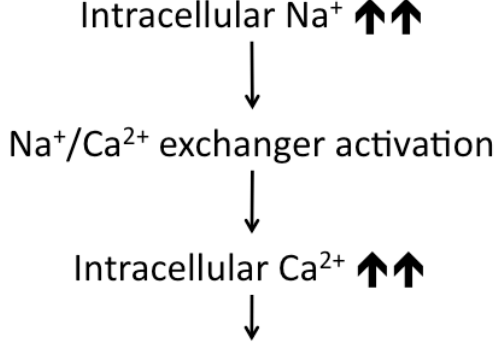

Cardiac contractility $\uparrow$

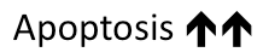

(B) New theory

Digitoxin (0.01-0.1 $\mu \mathrm{M})$

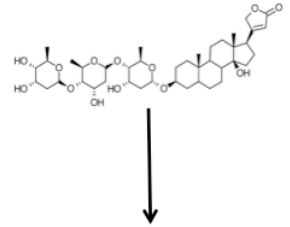

$\mathrm{Na}^{+} / \mathrm{K}^{+}$ATPase signalosome

(MAPK, SRC, Akt, and PLC signaling)

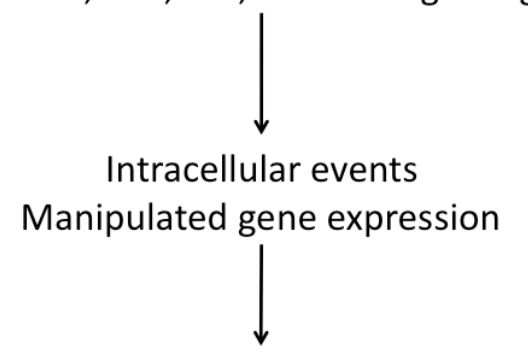

Anticancer effects

SCHEME 2: The effects of digitoxin on the $\mathrm{Na}^{+} / \mathrm{K}^{+} \mathrm{ATPase}$ at micromolar and at nanomolar concentrations respectively. (A) Old theory summarizes the effect of digitoxin at $0.5 \mu \mathrm{M}-5 \mu \mathrm{M}$ concentrations. (B) New theory summarizes digitoxin's effect at $0.01 \mu \mathrm{M}$ $-0.1 \mu \mathrm{M}$ concentrations.

In 2003, Xie and colleagues suggested that the signaling characteristics of $\mathrm{Na}^{+} / \mathrm{K}^{+} \mathrm{ATPase}$ are distinct from the ion pumping activity [37]. It was shown that $\mathrm{Na}^{+} / \mathrm{K}^{+}$ATPase signalosome is a multiple-protein signaling complex of 3 alpha $(\alpha)$ 
subunits and 2 beta $(\beta)$ subunits that controls cellular activities like apoptosis [38], cell proliferation [39], cell motility [40], and tight junctions [41]. Subsequently, it was proposed that digitoxin at nanomolar concentrations manipulates the $\mathrm{Na}^{+} / \mathrm{K}^{+} \mathrm{ATPase}$ signalosome to transmit intracellular signals. SCHEME 2B summarizes the intracellular effects of digitoxin upon binding to $\mathrm{Na}^{+} / \mathrm{K}^{+}$ATPase at concentrations between $(10 \mathrm{nM}-100 \mathrm{nM})$. Upon binding, digitoxin manipulates the $\mathrm{Na}^{+} / \mathrm{K}^{+}$ATPase protein complex activating the associated downstream signaling pathways, i.e. activation of several signaling cascades such as as phospholipase C (PLC) signaling, mitogen-activated protein kinase (MAPK) signaling, Phosphatidylinositol-3-Kinase (PI3K) signaling and Src kinase signaling.

The signaling cascades that are stimulated upon the interaction of digitoxin with $\mathrm{Na}^{+} / \mathrm{K}^{+} \mathrm{ATPase}$ have mixed functions. For example, the MAPK signaling is mainly a proliferative and a pro-survival signaling, that can also be complemented by pro-apoptotic signaling capability [42-48]. Src kinase signaling is a non-receptor tyrosine kinase that exhibits pro-survival as well as pro-apoptotic functions [49-57]. Therefore, digitoxin's ability to manipulate the signaling exploited downstream $\mathrm{Na}^{+} / \mathrm{K}^{+} \mathrm{ATPase}$ signalosome is very complex. Such complexity together with the digitoxin's narrow therapeutic window and its know characteristic cardiotoxicity $[1,2,18,58]$, led to a slow progress in developing digitoxin as anticancer drugs.

\section{DESIGNING DIGITOXIN ANALOGS AS EFFECTIVE ANTICANCER DRUGS}

Early on it was suggested that a potential approach to circumvent digitoxin's cardiotoxicity is to design synthetic analogs that are either more effective or less toxic than digitoxin when used as anticancer drugs $[8,59]$. Such analogs were designed by 
structural modification of digitoxin's chemical entity. For example, using digitoxin as a model, Langenhan and colleagues developed MeON-neoglycosylation, a chemoselective method for glycorandomization that employs modifying the glycosidic bond that links the saccharide moiety to the CG core steroidal nucleus of digitoxin [59].

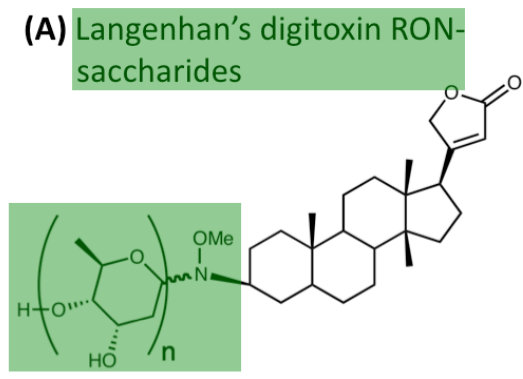

$\mathbf{n = 1 ;}$ Digitoxin mono-MeONsaccharide $\mathbf{n = 2 ;}$ Digitoxin di-MeON-saccharide $\mathbf{n = 3 ;}$ Digitoxin tri-MeON-saccharide
(B) O'Doherty's digitoxin O-

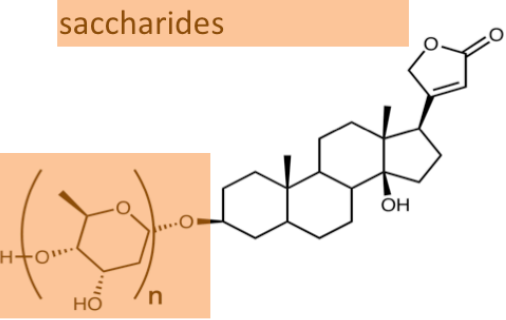

$\mathbf{n = 1}$; Digitoxin mono-O-saccharide $\mathbf{n = 2 ;}$ Digitoxin di-O-saccharide

$\mathrm{n}=3$; Digitoxin

$\mathrm{n}=\boldsymbol{\alpha}$-L-rhamnose; $D 6-M A$

SCHEME 3: The structures of novel digitoxin analogs. (A) The common structural motif of a neoglycoside molecule developed by Langenhan and colleagues and characterized by a tertiary amine bond linking the saccharide moiety to the steroidal nucleus. (B) The common structural motif of a digitoxin O-saccharide molecule developed by O'Doherty and colleagues is characterized by an ether bond that links the saccharide moiety to the steroidal nucleus.

In 2008, Zhou and O'Doherty developed another method for modifying the glycosidic linkage of digitoxin using palladium-catalyzed glycosylation [60, 61]. O'Doherty's analogs are characterized by an ether linkage between the saccharide moiety and the steroidal nucleus. As result, novel synthetic digitoxin O-glycoside analogs were also synthesized $[9,60,61]$. SCHEME 3 shows the core structures of digitoxin analogs synthesized by Langenhan and colleagues, and O'Doherty and colleagues respectively.

The differential potency and cytotoxic selectivity of digitoxin MeON-Neoglycosides 
and digitoxin O-glycosides respectively was tested against different cancer cell lines. For instance, lyer and colleagues compared a library of different digitoxin MeONNeoglycosides and digitoxin O-glycosides in a panel of 60 different cancer cell lines [9]. They showed that O-glycosides are more potent anticancer agents when compared to MeON-Neoglycosides, in a variety of cancer cell lines from leukemia, to lung, pancreatic and breast cancer cells. Additionally, the authors also showed that analog potency depends on the sugar moiety with the monosaccharide of digitoxin being more potent than the disaccharide and the trisaccharide analog respectively.

Wang and colleagues tested artificial O-monosaccharide analogs against a panel of 60 different cancer cell lines [62-64]. Authors identified three digitoxin monosaccharide analogs that showed significantly greater cytotoxic potential against non-small cell lung cancer (NSCLC) cells [62-64]. The most promising of these analogs, D6-MA, was subsequently chosen by Elbaz and colleagues for further mechanistic studies in order to unravel its anticancer mechanism [36].

\section{ANTICANCER MECHANISM AND SELECTIVITY OF DIGITOXIN AND D6-MA}

Elbaz and colleagues showed that the D6-MA analog was 4-5 fold more potent than digitoxin in inhibiting cell proliferation, inducing cell cycle arrest and apoptosis in NSCLC cells [36]. Authors also showed that digitoxin and D6-MA exhibited significantly greater cytotoxicity against NSCLC, when compared to both primary and non-tumorigenic lung epithelial lines being tested. The selective cytotoxicity in lung cancer cells induced G2/M phase arrest and apoptosis [36]. Moreover, digitoxin and D6-MA inhibited the expression of p53, cdc2, cyclinB1, survivin, and Chk1/2. 
In order to explain the observed anticancer mechanism, we now postulate that digitoxin and D6-MA manipulate several transcriptional regulatory cascades via $\mathrm{Na}^{+} / \mathrm{K}^{+}$ATPase signalosome $[37,65-72]$. Our suggested mechanism to mediate the observed selective cytotoxic effect leads to a reduction in the expression of cell cycle regulatory proteins that are specifically over expressed in cancer cells when compared to normal cells. FIGURE 1 illustrates how digitoxin manipulates gene expression of these cancer specific proteins.

Our assumption is based on previous studies that showed that digitoxin potentially inhibits AP-1 signaling and NF-KB signaling through manipulating the $\mathrm{Na}^{+} / \mathrm{K}^{+} \mathrm{ATPase}$ signalosome $[68,73-79]$. AP-1 is a transcriptional factor that promotes the expression of cell cycle regulatory proteins, such as cdc2 and cyclinB1 [80-82]. Several studies showed that cyclinB1 is essential for cell viability $[83,84]$. CyclinB1 and cdc2 are specifically overexpressed in cancer cells [85-90], and complex with each other prior to mitosis. They catalyze chromatin condensation as well as nuclear envelope breakdown during mitosis [91, 92]. cyclinB1/cdc2 complex performs a rate limiting function in G2/M phase transition and protects mitotic cells from apoptosis by activating survivin. Survivin is a vital cell cycle regulatory protein that is specifically overexpressed in different cancer types [93-98]. Survivin controls progression through mitosis by promoting the chromosomal passenger complex, and regulating microtubule dynamics [99-102]. Additionally, survivin regulates the mitotic spindle checkpoint [103-106]. Several studies pointed to survivin downregulation as being a biomarker for mitotic catastrophe [107-109].

Additionally, NF-KB transcriptional factor regulates the expression of cell cycle regulatory proteins such as survivin [110]. Thus, by inhibiting both AP-1 and NF-kB 
signaling, digitoxin and D6-MA potentially inhibit the expression of cdc2, cyclinB1, survivin, and Chk1/2 as shown in SCHEMES 2 and FIGURE 1. Moreover, the association of cyclinB1/cdc2 complex with survivin indicates that the complex is crucial for G2/M phase transition and cell viability, and inhibiting its expression by both digitoxin and D6MA could potentially explain the selective cytotoxicity of these compounds towards cancer cells.

Since inhibiting Chk1/2 typically elicits checkpoint abrogation, uncontrolled cell cycle progression and abolished cell viability [111-113], a potential alternative mechanism by which digitoxin and D6-MA inhibit cell viability can be their ability to cause checkpoint abrogation. It is quite unclear, though, how digitoxin and D6-MA inhibit checkpoint kinase proteins in cancer cells. Distinguishing between CGs-induced cell cycle arrest and/or checkpoint abrogation will further enhance our understanding of how CGs such as digitoxin and analog leads to anti-proliferative/cell death effect.

\section{CONCLUSIONS AND OUTLOOK}

Digitoxin and D6-MA strongly modulate cell cycle machinery through the $\mathrm{Na}^{+} / \mathrm{K}^{+}$ATPase signalosome in a manner that significantly undermines cell viability (FIGURE 1). However several questions remain unanswered regarding their mechanistic control of cancer cell cycle. 


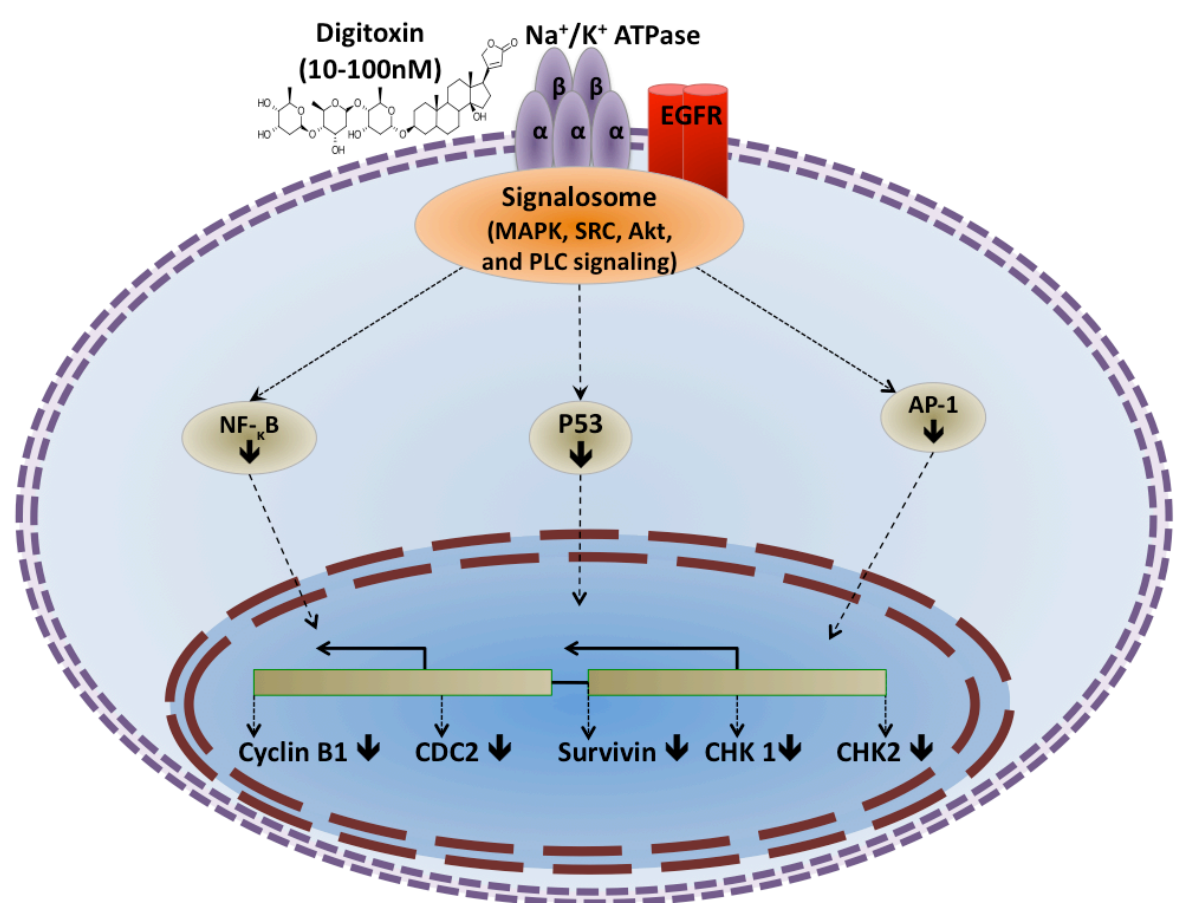

FIGURE 1: Digitoxin manipulates the $\mathrm{Na}^{+} / \mathrm{K}^{+} A T P a s e$ signalosome and inhibits the transcriptional activity of AP-1 and NF-KB, which mediate the expression of cancer specific cycle regulatory genes as cyclin $\mathrm{B} 1, \mathrm{cdc} 2, \mathrm{Chk} 1, \mathrm{Chk} 2$, and survivin.

Delineating the mechanism(s) of cell cycle arrest and selectivity of the digitoxin and analogs towards cancer cells has several advantages. First, it will increase our understanding how digitoxin and analog cause G2/M phase arrest in cancer cells. Secondly, it will help identify novel p53-independent therapeutic target(s) to mediate cancer cell death. Since many cancer types develop resistance to chemotherapy by reducing p53 expression and signaling [114-124], identifying p53-independent therapeutic target(s) will contribute to developing new and more effective chemotherapeutic alternatives for cancer by circumventing p53 related resistance mechanisms. Also, detailing how digitoxin and D6-MA inhibit survivin expression in cancer cells will improve our understanding of how digitoxin and analog cause G2/M phase arrest and apoptosis. 
Additionally, understanding how digitoxin and D6-MA inhibit survivin and p53 expression in cancer cells would show whether the compounds induce mitotic catastrophe, and if so, how. Answering these questions will escalate our understanding of the antineoplastic mechanism of CGs at therapeutically relevant concentrations in cancer cells, thus opening new and more effective chemotherapeutic alternatives.

\section{REFERENCES}

1. Prassas I, Diamandis EP: Novel therapeutic applications of cardiac glycosides. Nature reviews Drug discovery 2008, 7(11):926-935.

2. Newman RA, Yang P, Pawlus AD, Block Kl: Cardiac Glycosides as Novel Cancer Therapeutic Agents. Molecular Interventions 2008, 8(1):36-49.

3. Huxtable RJ: The Erroneous Pharmacology of a Cat. Molecular interventions 2001, 1(2):75-77.

4. Gheorghiade M, van Veldhuisen DJ, Colucci WS: Contemporary Use of Digoxin in the Management of Cardiovascular Disorders. Circulation 2006, 113(21):2556-2564.

5. Rahimtoola SH, Tak T: The use of digitalis in heart failure. Current Problems in Cardiology 1996, 21(12):781-853.

6. Schonfeld W: The lead structure in cardiac glycosides is 5 [beta],14[beta]androstane-3[beta]14-diol. Naunyn Schmiedebergs Arch Pharmacol 1985, 329:414-426.

7. Melero CP, Medardea M, Feliciano AS: A short review on cardiotonic steroids and their aminoguanidine analogues. Molecules 2000, 5:51-81. 
8. Langenhan JM, Peters NR, Guzei IA, Hoffmann M, Thorson JS: Enhancing the anticancer properties of cardiac glycosides by neoglycorandomization. Proceedings of the National Academy of Sciences of the United States of America 2005, 102(35):12305-12310.

9. Iyer AKV, Zhou M, Azad N, Elbaz H, Wang L, Rogalsky DK, Rojanasakul Y, O'Doherty GA, Langenhan JM: A Direct Comparison of the Anticancer Activities of Digitoxin MeON-Neoglycosides and O-Glycosides: Oligosaccharide Chain Length-Dependent Induction of Caspase-9-Mediated Apoptosis. ACS Medicinal Chemistry Letters 2010, 1(7):326-330.

10. Barry W, Hasin $\mathrm{Y}$, Smith $\mathrm{T}$ : Sodium pump inhibition, enhanced calcium influx via sodium-calcium exchange, and positive inotropic response in cultured heart cells. Circ Res 1985, 56(2):231-241.

11. Kaplan JH: Biochemistry of Na, K-ATPase. Annu Rev Biochem 2002, 71:511535.

12. Kaplan JG: Membrane cation transport and the control of proliferation of mammalian cells. Annu Rev Physiol 1978, 40:19-41.

13. Brewer H: Historical perspectives on health. The Journal of the Royal Society for the Promotion of Health 2004, 124(4):184-187.

14. Watabe M, Masuda Y, Nakajo S, Yoshida T, Kuroiwa Y, Nakaya K: The Cooperative Interaction of Two Different Signaling Pathways in Response to Bufalin Induces Apoptosis in Human Leukemia U937 Cells. Journal of Biological Chemistry 1996, 271(24):14067-14073. 
15. Yeh JY, Huang WJ, Kan SF, Wang PS: Effects of bufalin and cinobufagin on the proliferation of androgen dependent and independent prostate cancer cells. Prostate 2003, 54(2):112-124.

16. Han KQ: Anti-tumor activities and apoptosis-regulated mechanisms of bufalin on the orthotopic transplantation tumor model of human hepatocellular carcinoma in nude mice. World J Gastroenterol 2007, 13:33743379.

17. Shiratori O: Growth inhibitory effect of cardiac glycosides and aglycones on neoplastic cells: in vitro and in vivo studies. Gann 1967, 58(6):521-528.

18. López-Lázaro M: Digitoxin as an anticancer agent with selectivity for cancer cells: possible mechanisms involved. Expert Opin Ther Targets 2007, 11(8):1043-1053.

19. Stenkvist B: Cardiac glycosides and breast cancer. Lancet 1979, 1:563.

20. Stenkvist B: Evidence of a modifying influence of heart glucosides on the development of breast cancer. Anal Quant Cytol 1980, 2:49-54.

21. Stenkvist B: Cardiac glycosides and breast cancer, revisited. N Engl J Med 1982, 306:484.

22. Stenkvist B: Is digitalis a therapy for breast carcinoma? Oncol Rep 1999, 6:493-496.

23. Goldin AG, Safa AR: Digitalis and cancer. Lancet 1984, 1:1134.

24. Belz GG, K. B-G, Osowski U: Treatment of congestive heart failure--current status of use of digitoxin. Eur J Clin Invest 2001, 31 Suppl 2:10-17. 
25. Castle MC: Pharmacokinetics of digitoxin and digitoxin in humans. In.: EASTERN VIRGINIA MED SCH/MED COL HAMP RD; 1977.

26. BøHMER T, RøSETH A: Prolonged digitoxin half-life in very elderly patients. Age Ageing 1998, 27(2):222-224.

27. Smith TW: Digitalis toxicity: epidemiology and clinical use of serum concentration measurements. Am J Med 1975, 58(4):470-476.

28. Williams JF, Jr., Potter RD, Mathew B: Effects of arrhythmia-producing concentrations of digitoxin on mechanical performance of cat myocardium. Am Heart J 1983, 105(1):21-25.

29. Haux J: Digitoxin is a potential anticancer agent for several types of cancer. Medical Hypotheses 1999, 53(6):543-548.

30. Lopez-Lazaro M, Pastor N, Azrak SS, Ayuso MJ, Austin CA, Cortes F: Digitoxin inhibits the growth of cancer cell lines at concentrations commonly found in cardiac patients. J Nat Prod 2005, 68(11):1642-1645.

31. Kometiani P, Liu L, Askari A: Digitalis-Induced Signaling by $\mathbf{N a + / K + - A T P a s e ~ i n ~}$ Human Breast Cancer Cells. Mol Pharmacol 2005, 67(3):929-936.

32. Schatzmann HJ, Rass B: Inhibition of the active Na-K-transport and Na-Kactivated membrane ATP-ase of erythrocyte stroma by ouabain. Helv Physiol Pharmacol Acta 1965, 65:C47-C49.

33. Chang HT, Huang JK, Wang JL, Cheng JS, Lee KC, Lo YK, Liu CP, Chou KJ, Chen WC, Su W et al: Tamoxifen-induced increases in cytoplasmic free Ca-2+ levels in human breast cancer cells. Breast Cancer Research and Treatment 2002, 71(2):125-131. 
34. Koumura T, Nakamura C, Nakagawa Y: Role of calcium-induced mitochondrial hydroperoxide in induction of apoptosis of RBL2H3 cells with eicosapentaenoic acid treatment. Free Radical Research 2005, 39(10):10831089.

35. Pigozzi D, Tombal B, Ducret T, Vacher P, Gailly P: Role of store-dependent influx of Ca2+ and efflux of $\mathrm{K}+$ in apoptosis of CHO cells. Cell Calcium 2004, 36(5):421-430.

36. Elbaz HA, Stueckle TA, Wang H-YL, O'Doherty G, Lowry DT, Sargent LM, Wang L, Dinu CZ, Rojanasakul Y: Digitoxin and a synthetic monosaccharide analog inhibit cell viability in lung cancer cells. Toxicology and Applied Pharmacology (0).

37. Xie Z, Cai T: Na+/K+ATPase-Mediated Signal Transduction: From Protein Interaction to Cellular Function. Molecular Interventions 2003, 3(3):157-168.

38. Wang XQ: Apoptotic insults impair $\mathrm{Na}+\mathrm{K}+-\mathrm{ATPase}$ activity as a mechanism of neuronal death mediated by concurrent ATP deficiency and oxidant stress. J Cell Sci 2003, 116:2099-2110.

39. Liu L, Abramowitz J, Askari A, Allen JC: Role of caveolae in ouabain-induced proliferation of cultured vascular smooth muscle cells of the synthetic phenotype. Am J Physiol Heart Circ Physiol 2004, 287:H2173-H2182.

40. Barwe SP: Novel role for $\mathrm{Na}, \mathrm{K}-\mathrm{ATPase}$ in phosphatidylinositol 3-kinase signaling and suppression of cell motility. Mol Biol Cell 2005, 16:1082-1094.

41. Larre I, Lazaro A, Contreras RG, Balda MS, Matter K, Flores-Maldonado C, Ponce A, Flores-Benitez D, Rincon-Heredia R, Padilla-Benavides $\mathrm{T}$ et al: Ouabain 
modulates epithelial cell tight junction. Proceedings of the National Academy of Sciences 2010, 107(25):11387-11392.

42. Bulavin DV, Fornace AJ, Jr.: p38 MAP kinase's emerging role as a tumor suppressor. Adv Cancer Res 2004, 92:95-118.

43. Cagnol S, Chambard J-C: ERK and cell death: mechanisms of ERK-induced cell death--apoptosis, autophagy and senescence. FEBS J 2009, 277(1):2-21.

44. de Paula RM, Lamb TM, Bennett L, Bell-Pedersen D: A connection between MAPK pathways and circadian clocks. Cell Cycle 2008, 7(17):2630-2634.

45. Gotoh I, Nishida E: [Signal transductions by the MAP kinase cascades]. Nippon Rinsho 1998, 56(7):1779-1783.

46. Han J, Sun P: The pathways to tumor suppression via route $\mathrm{p} 38$. Trends in Biochemical Sciences 2007, 32(8):364-371.

47. Keyse SM: Dual-specificity MAP kinase phosphatases (MKPs) and cancer. Cancer Metastasis Rev 2008, 27(2):253-261.

48. Khavari TA, Rinn J: Ras/Erk MAPK signaling in epidermal homeostasis and neoplasia. Cell Cycle 2007, 6(23):2928-2931.

49. Bolós V, Gasent JM, López-Tarruella S, Grande E: The dual kinase complex FAK-Src as a promising therapeutic target in cancer. Onco Targets Ther 2010, 3:83-97.

50. Burnham MR, Bruce-Staskal PJ, Harte MT, Weidow CL, Ma A, Weed SA, Bouton $\mathrm{AH}$ : Regulation of c-SRC activity and function by the adapter protein CAS. Mol Cell Biol 2000, 20(16):5865-5878. 
51. Chen C-Y, Chang C-Y, Liu H-J, Liao M-H, Chang C-I, Hsu J-L, Shih W-L: Apoptosis induction in BEFV-infected Vero and MDBK cells through Srcdependent JNK activation regulates caspase-3 and mitochondria pathways. Vet Res 2010, 41(2).

52. Di Florio A, Capurso G, Milione M, Panzuto F, Geremia R, Delle Fave G, Sette C: Src family kinase activity regulates adhesion, spreading and migration of pancreatic endocrine tumour cells. Endocr Relat Cancer 2007, 14(1):111-124.

53. Götz R: Inter-cellular adhesion disruption and the RAS/RAF and beta-catenin signalling in lung cancer progression. Cancer Cell Int 2008, 8(1):7.

54. Liu Y, Gao L, Gelman IH: SSeCKS/Gravin/AKAP12 attenuates expression of proliferative and angiogenic genes during suppression of v-Src-induced oncogenesis. BMC Cancer 2006, 6(1):105.

55. Owen KA, Abshire MY, Tilghman RW, Casanova JE, Bouton AH: FAK Regulates Intestinal Epithelial Cell Survival and Proliferation during Mucosal Wound Healing. PLoS One 2011, 6(8).

56. Schiemann W: Integrin-Mediated Regulation of TGF-Beta Signaling and Tumorigenesis. In.: NATIONAL CANCER INSTITUTE; 2007.

57. Williams SP, Karnezis T, Achen MG, Stacker SA: Targeting lymphatic vessel functions through tyrosine kinases. J Angiogenes Res 2010, 2:13-13.

58. Winnicka K, Bielawski K, Bielawska A: Cardiac glycosides in cancer research and cancer therapy. Acta Pol Pharm 2006, 63(2):109-115. 
59. Langenhan JM, Engle JM, Slevin LK, Fay LR, Lucker RW, Smith KR, Endo MM: Modifying the glycosidic linkage in digitoxin analogs provides selective cytotoxins. Bioorganic \& Medicinal Chemistry Letters 2008, 18(2):670-673.

60. Zhou M, O'Doherty G: The De novo Synthesis of Oligosaccharides Application to the Medicinal Chemistry SAR Study of Digitoxin. Chemlnform 2008, 39(27):no-no.

61. Zhou M, O'Doherty G: The De Novo Synthesis of Oligosaccharides: Application to the Medicinal Chemistry SAR-Study of Digitoxin. Current Topics in Medicinal Chemistry 2008, 8:114-125.

62. Wang H-YL, Rojanasakul Y, O,ÄôDoherty GA: Synthesis and Evaluation of the a-d-/a-I-Rhamnosyl and Amicetosyl Digitoxigenin Oligomers as Antitumor Agents. ACS Medicinal Chemistry Letters 2011, 2(4):264-269.

63. Wang H-YL, Wu B, Zhang Q, Kang S-W, Rojanasakul Y, O,ÄôDoherty GA: C5'Alkyl Substitution Effects on Digitoxigenin $\alpha-I-G l y c o s i d e$ Cancer Cytotoxicity. ACS Medicinal Chemistry Letters 2011, 2(4):259-263.

64. Wang H-YL, Xin W, Zhou M, Stueckle TA, Rojanasakul Y, O'Doherty GA: Stereochemical Survey of Digitoxin Monosaccharides. ACS Medicinal Chemistry Letters 2010, 2(1):73-78.

65. Kometiani P, Li J, Gnudi L, Kahn BB, Askari A, Xie Z: Multiple signal transduction pathways link $\mathrm{Na}+/ \mathrm{K}+-\mathrm{ATPase}$ to growth-related genes in cardiac myocytes. The roles of Ras and mitogen-activated protein kinases. $J$ Biol Chem 1998, 273(24):15249-15256. 
66. Liu L, Askari A: On the importance and mechanism of amplification of digitalis signal through Na+/K+-ATPase. Cell Mol Biol (Noisy-le-grand) 2006, 52(8):2830.

67. Mohammadi K, Kometiani $\mathrm{P}$, Xie Z, Askari A: Role of protein kinase $\mathrm{C}$ in the signal pathways that link Na+/K+-ATPase to ERK1/2. J Biol Chem 2001, 276:42050-42056.

68. Peng $M$, Huang $L$, Xie Z, Huang WH, Askari A: Partial inhibition of Na+/K+ATPase by ouabain induces the $\mathrm{Ca}$ 2+-dependent expressions of earlyresponse genes in cardiac myocytes. J Biol Chem 1996, 271(17):10372-10378.

69. Schoner W, Scheiner-Bobis G: Endogenous and exogenous cardiac glycosides: their roles in hypertension, salt metabolism, and cell growth. Am J Physiol Cell Physiol 2007, 293(2):C509-536.

70. Xie Z, Kometiani P, Liu J, Li J, Shapiro Jl, Askari A: Intracellular reactive oxygen species mediate the linkage of $\mathrm{Na} / \mathrm{K}+-\mathrm{ATPase}$ to hypertrophy and its marker genes in cardiac myocytes. J Biol Chem 1999, 274(27):19323-19328.

71. $\mathrm{Xu} \mathrm{J-W,} \mathrm{Jin} \mathrm{R-M,} \mathrm{Wang} \mathrm{Y-R,} \mathrm{Lin} \mathrm{W,} \mathrm{Meng} \mathrm{B:} \mathrm{[Effects} \mathrm{of} \mathrm{ouabain} \mathrm{at} \mathrm{different}$ concentrations on growth of leukemia cells]. Zhongguo Dang Dai Er Ke Za Zhi 2009, 11(4):259-262.

72. Yuan Z: Na/K-ATPase tethers phospholipase C and IP3 receptor into a calcium-regulatory complex. Mol Biol Cell 2005, 16:4034-4045.

73. Dueñas-González A, García-López P, Herrera LA, Medina-Franco JL, GonzálezFierro A, Myrna C: The prince and the pauper. A tale of anticancer targeted agents. Mol Cancer 2008, 7(1):82. 
74. Manna SK, Sah NK, Newman RA, Cisneros A, Aggarwal BB: Oleandrin suppresses activation of nuclear transcription factor-kappa B, activator protein-1, and C-Jun NH2-terminal kinase. Cancer Research 2000, 60(14):38383847.

75. Shull MM, Pugh DG, Lingrel JB: Characterization of the human Na,K-ATPase alpha 2 gene and identification of intragenic restriction fragment length polymorphisms. J Biol Chem 1989, 264(29):17532-17543.

76. Sreenivasan $\mathrm{Y}$, Sarkar A, Manna SK: Oleandrin suppresses activation of nuclear transcription factor-kappa B and activator protein-1 and potentiates apoptosis induced by ceramide. Biochemical Pharmacology 2003, 66(11):22232239.

77. Jagielska J, Salguero G, Schieffer B, Bavendiek U: Digitoxin elicits antiinflammatory and vasoprotective properties in endothelial cells: Therapeutic implications for the treatment of atherosclerosis? Atherosclerosis 2009, 206(2):390-396.

78. Srivastava M, Eidelman O, Zhang J, Paweletz C, Caohuy H, Yang Q, Jacobson KA, Heldman E, Huang W, Jozwik $C$ et al: Digitoxin mimics gene therapy with CFTR and suppresses hypersecretion of IL-8 from cystic fibrosis lung epithelial cells. Proceedings of the National Academy of Sciences of the United States of America 2004, 101(20):7693-7698.

79. Yang Q, Huang W, Jozwik C, Lin Y, Glasman M, Caohuy H, Srivastava M, Esposito D, Gillette W, Hartley J et al: Cardiac glycosides inhibit TNF-alpha/NFkappaB signaling by blocking recruitment of TNF receptor-associated death 
domain to the TNF receptor. Proceedings of the National Academy of Sciences of the United States of America 2005, 102(27):9631-9636.

80. Bamberger AM, Milde-Langosch $\mathrm{K}, \mathrm{R} \sqrt{ } \partial \mathrm{ss} i n g$ E, Goemann $\mathrm{C}, \mathrm{L} \sqrt{ } \partial \mathrm{n} i n g \mathrm{~T}$ : Expression pattern of the AP-1 family in endometrial cancer: correlations with cell cycle regulators. J Cancer Res Clin Oncol 2001, 127(9):545-550.

81. Dumesic PA, Scholl FA, Barragan DI, Khavari PA: Erk1/2 MAP kinases are required for epidermal G2/M progression. J Cell Biol 2009, 185(3):409-422.

82. Karamouzis MV, Konstantinopoulos PA, Papavassiliou AG: The Activator Protein-1 Transcription Factor in Respiratory Epithelium Carcinogenesis. Molecular Cancer Research 2007, 5(2):109-120.

83. Crombez L, Morris MC, Dufort S, Aldrian-Herrada G, Nguyen Q, Mc Master G, Coll J-L, Heitz F, Divita G: Targeting cyclin B1 through peptide-based delivery of siRNA prevents tumour growth. Nucleic Acids Res 2009, 37(14):4559-4569.

84. Yuan J, Yan R, Kramer A, Eckerdt F, Roller M, Kaufmann M, Strebhardt K: Cyclin B1 depletion inhibits proliferation and induces apoptosis in human tumor cells. Oncogene 2004, 23(34):5843-5852.

85. Chae SW, Sohn JH, Kim D-H, Choi YJ, Park YL, Kim K, Cho YH, Pyo J-S, Kim JH: Overexpressions of Cyclin B1, cdc2, p16 and p53 in Human Breast Cancer: The Clinicopathologic Correlations and Prognostic Implications. Yonsei Med J 2011, 52(3):445-453.

86. Cooper WA, Kohonen-Corish MRJ, McCaughan B, Kennedy C, Sutherland RL, Lee CS: Expression and prognostic significance of cyclin B1 and cyclin A in non-small cell lung cancer. Histopathology 2009, 55(1):28-36. 
87. Egloff AM, Weissfeld J, Land SR, Finn OJ: Evaluation of anticyclin B1 serum antibody as a diagnostic and prognostic biomarker for lung cancer. Annals of the New York Academy of Sciences 2005, 1062:29-40.

88. Kim D-H: Prognostic implications of cyclin B1, p34cdc2, p27(Kip1) and p53 expression in gastric cancer. Yonsei Med J 2007, 48(4):694-700.

89. Wong Y-F, Cheung T-H, Tsao GSW, Lo KWK, Yim S-F, Wang VW, Heung MMS, Chan SCS, Chan LKY, Ho TWF et al: Genome-wide gene expression profiling of cervical cancer in Hong Kong women by oligonucleotide microarray. Int $J$ Cancer 2006, 118(10):2461-2469.

90. Yoshida T, Tanaka S, Mogi A, Shitara Y, Kuwano H: The clinical significance of Cyclin B1 and Wee1 expression in non-small-cell lung cancer. Ann Oncol 2004, 15(2):252-256.

91. De Souza CP, Ellem KA, Gabrielli BG: Centrosomal and cytoplasmic Cdc2/cyclin B1 activation precedes nuclear mitotic events. Exp Cell Res 2000, 257(1):11-21.

92. Stark G, Taylor W: Control of the G2/M transition. Molecular Biotechnology 2006, 32(3):227-248.

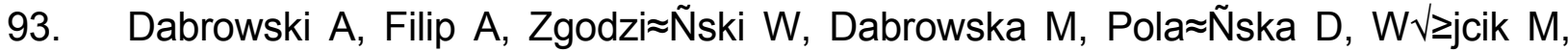
Zinkiewicz K, Wallner G: Assessment of prognostic significance of cytoplasmic survivin expression in advanced oesophageal cancer. Folia Histochem Cytobiol 2004, 42(3):169-172. 
94. Falleni M, Pellegrini C, Marchetti A, Oprandi B, Buttitta F, Barassi F, Santambrogio L, Coggi G, Bosari S: Survivin gene expression in early-stage non-small cell lung cancer. J Pathol 2003, 200(5):620-626.

95. He L, Hou M, Zhang J, Xu N, Chen P: [Subcellular localization of survivin in non-small cell lung cancer]. Ai Zheng 2009, 28(9):955-960.

96. Ren $Y-j$, Zhang Q-y: [Expression of survivin and its clinical significance in non-small cell lung cancer]. Beijing Da Xue Xue Bao 2005, 37(5):504-507.

97. Yang H, Fu J-h, Hu Y, Huang W-z, Zheng B, Wang G: [Relationship between survivin expression and chemosensitivity of human lung cancer cells]. Zhonghua Yi Xue Za Zhi 2007, 87(27):1934-1937.

98. Zhou J-M, Zhou J-H, Deng Z-H, Zheng H, Jiang H-Y, Cao H-Q: [Expression of survivin and proliferating cell nuclear antigen in human non-small cell lung cancer]. Zhong Nan Da Xue Xue Bao Yi Xue Ban 2005, 30(5):544-548.

99. Beardmore VA, Ahonen LJ, Gorbsky GJ, Kallio MJ: Survivin dynamics increases at centromeres during G2/M phase transition and is regulated by microtubule-attachment and Aurora B kinase activity. Journal of cell science 2004, 117(Pt 18):4033-4042.

100. Beltrami E, Plescia J, Wilkinson JC, Duckett CS, Altieri DC: Acute Ablation of Survivin Uncovers p53-dependent Mitotic Checkpoint Functions and Control of Mitochondrial Apoptosis. Journal of Biological Chemistry 2004, 279(3):20772084. 
101. Mita AC, Mita MM, Nawrocki ST, Giles FJ: Survivin: Key Regulator of Mitosis and Apoptosis and Novel Target for Cancer Therapeutics. Clinical Cancer Research 2008, 14(16):5000-5005.

102. Wolanin K, Piwocka K: [Role of survivin in mitosis]. Postepy Biochem 2007, 53(1):10-18.

103. Colnaghi R, Wheatley SP: Liaisons between survivin and Plk1 during cell division and cell death. J Biol Chem 2010, 285(29):22592-22604.

104. Lens SMA, Wolthuis RMF, Klompmaker R, Kauw J, Agami R, Brummelkamp T, Kops G, Medema RH: Survivin is required for a sustained spindle checkpoint arrest in response to lack of tension. EMBO J 2003, 22(12):2934-2947.

105. Li F, Ackermann EJ, Bennett CF, Rothermel AL, Plescia J, Tognin S, Villa A, Marchisio PC, Altieri DC: Pleiotropic cell-division defects and apoptosis induced by interference with survivin function. Nat Cell Biol 1999, 1(8):461466.

106. Li F, Ambrosini G, Chu EY, Plescia J, Tognin S, Marchisio PC, Altieri DC: Control of apoptosis and mitotic spindle checkpoint by survivin. Nature 1998, 396(6711):580-584.

107. Castedo M, Perfettini J-L, Roumier T, Andreau K, Medema R, Kroemer G: Cell death by mitotic catastrophe: a molecular definition. Oncogene 2004, 23(16):2825-2837.

108. Okada H, Mak TW: Pathways of apoptotic and non-apoptotic death in tumour cells. Nat Rev Cancer 2004, 4(8):592-603. 
109. Vakifahmetoglu H, Olsson M, Zhivotovsky B: Death through a tragedy: mitotic catastrophe. Cell Death Differ 2008, 15(7):1153-1162.

110. Barre' B, Perkins ND: A cell cycle regulatory network controlling NF-kappaB subunit activity and function. EMBO J 2007, 26(23):4841-4855.

111. Bartek J, Lukas J: Chk1 and Chk2 kinases in checkpoint control and cancer. Cancer Cell 2003, 3:421-429.

112. Zhou B-BS, Bartek J: Targeting the checkpoint kinases: chemosensitization versus chemoprotection. Nat Rev Cancer 2004, 4(3):216-225.

113. Zhou B-BS, Sausville EA: Drug discovery targeting Chk1 and Chk2 kinases. Prog Cell Cycle Res 2003, 5:413-421.

114. Bell HS, Ryan KM: Targeting the p53 family for cancer therapy: 'big brother' joins the fight. Cell Cycle 2007, 6(16):1995-2000.

115. Bixby D, Kujawski L, Wang S, Malek SN: The pre-clinical development of MDM2 inhibitors in chronic lymphocytic leukemia uncovers a central role for p53 status in sensitivity to MDM2 inhibitor-mediated apoptosis. Cell Cycle 2008, 7(8):971-979.

116. Duiker EW, Mom CH, de Jong S, Willemse PHB, Gietema JA, van der Zee AGJ, de Vries EGE: The clinical trail of TRAIL. Eur J Cancer 2006, 42(14):2233-2240.

117. Fava C, Kantarjian H, Cortes J, Jabbour E: Development and targeted use of nilotinib in chronic myeloid leukemia. Drug Des Devel Ther 2009, 2:233-243.

118. Lebedeva IV, Su ZZ, Sarkar D, Fisher PB: Restoring apoptosis as a strategy for cancer gene therapy: focus on p53 and mda-7. Semin Cancer Biol 2003, 13(2):169-178. 
119. Lowe SW: Cancer therapy and p53. Curr Opin Oncol 1995, 7(6):547-553.

120. Pietersen A, Noteborn HM: Apoptin. Adv Exp Med Biol 2000, 465:153-161.

121. Sanlioglu AD, Aydin C, Bozcuk H, Terzioglu E, Sanlioglu S: Fundamental principals of tumor necrosis factor-alpha gene therapy approach and implications for patients with lung carcinoma. Lung cancer (Amsterdam, Netherlands) 2004, 44(2):199-211.

122. Toren A, Amariglio N, Rechavi G: Curable and non-curable malignancies: lessons from paediatric cancer. Med Oncol 1996, 13(1):15-21.

123. Vigneron $\mathrm{A}$, Vousden $\mathrm{KH}$ : $\mathrm{p} 53$, ROS and senescence in the control of aging. Aging (Albany NY) 2010, 2(8):471-474.

124. Watson AJ: Review article: manipulation of cell death--the development of novel strategies for the treatment of gastrointestinal disease. Aliment Pharmacol Ther 1995, 9(3):215-226. 


\section{CHAPTER 2}

\section{DIGITOXIN AND A SYNTHETIC MONOSACCHARIDE ANALOG INHIBIT CELL VIABILITY IN LUNG CANCER CELLS}

\section{ABSTRACT}

Mechanisms of digitoxin-inhibited cell growth and induced apoptosis in human nonsmall cell lung cancer ( $\mathrm{NCl}-\mathrm{H} 460)$ cells remain unclear. Understanding how digitoxin or derivate analogs induce their cytotoxic effect below therapeutically relevant concentrations will help in designing and developing novel, safer and more effective anticancer drugs. In this chapter, $\mathrm{NCl}-\mathrm{H} 460$ cells were treated with digitoxin and a synthetic analog D6-MA to determine their anti-cancer activity. Different concentrations of digitoxin and D6-MA were used and the subsequent changes in cell morphology, viability, cell cycle, and protein expressions were determined. Digitoxin and D6-MA induced dosedependent apoptotic morphologic changes in $\mathrm{NCl}-\mathrm{H} 460$ cells via caspase9 cleavage, with D6-MA possessing 5-fold greater potency than digitoxin. In comparison, non-tumorigenic immortalized bronchial and small airway epithelial cells displayed significantly less apoptotic sensitivity compared to $\mathrm{NCl}-\mathrm{H} 460$ cells suggesting that both digitoxin and D6MA were selective for NSCLC. Furthermore, NCl-H460 cells arrested in G2/M phase following digitoxin and D6-MA treatment. Post-treatment evaluation of key G2/M checkpoint regulatory proteins identified down-regulation of cyclinB1/cdc2 complex and survivin. Additionally, Chk1/2 and p53 related proteins experienced down-regulation suggesting a p53-independent cell cycle arrest mechanism. In summary, digitoxin and 
D6-MA exert anti-cancer effects on $\mathrm{NCl}-\mathrm{H} 460$ cells through apoptosis or cell cycle arrest, with D6-MA showing at least 5-fold greater potency relative to digitoxin.

\section{INTRODUCTION}

Appropriate cell cycle progression is crucial for cell viability [1, 2]. Cardiac glycosides (CGs) are a class of natural products known for their cardiotonic and antineoplastic effects [3]. In vitro studies on CG pharmacodynamics showed apoptosis, autophagy, and cell cycle arrest; however, such effects were selective against tumor cells when compared to normal cells [3-6]. Digitoxin, a clinically approved CG for heart failure has shown anti-cancer effect in several types of cancer [6]. For instance, Stenkvist et al. (1982) found that breast cancer patients on digitoxin regiment (20 nM - 33 nM) displayed improved outcomes than untreated patients [7, 8]. Digitoxin induces apoptosis and inhibits cancer cell growth by binding to the $\mathrm{Na}^{+} / \mathrm{K}^{+} \mathrm{ATPase}$ pump $[3,6]$. Digitoxin-bound $\mathrm{Na}^{+} / \mathrm{K}^{+}$ATPase activates tyrosine kinase Src, PI3K, phospholipase $\mathrm{C}$ and Ras/MAPK pathways which leads to antiproliferative downstream effects related to cell growth and apoptosis $[3,9]$. Given that the integrated sugars give the unique biological function of CGs [10-12], digitoxin provides an excellent model to efficiently modify its carbohydrate moiety and assess the biological impact of novel synthetic derivatives using cellularbased experiments. Therefore, synthesis of CG derivatives has become a potential approach for developing safer and more effective anti-neoplastic drugs.

Previous studies showed that modifying the glycosidic linkage or the oligosaccharide moiety of digitoxin could significantly enhance its anti-neoplastic activity [10-12]. In other studies, Wang et al. (2010) synthesized and compared stereochemistry 
structure/activity relationships of the carbohydrate moiety of several digitoxin monosaccharide analogs based on a 60 cancer cell line $\mathrm{NCl}$ screening for lethal and growth inhibitory effects. This screening showed that non-small cell lung cancer (NSCLC) cells were more sensitive to digitoxin and its analogs than many other cancer cell lines being tested $[10,13]$. Additionally, three monosaccharide analogues, namely $\beta$ Ddigitoxose, $\alpha$-L-rhamnose and $\alpha-L$ amicetose showed at least a 5 -fold increase in potency to induce apoptosis and growth inhibition in NSCLC [13-15]. However, these studies failed to identify the mechanisms mediating the anti-neoplastic effects of digitoxin or its synthetic analogs in cancer cells at/or below therapeutically relevant concentrations. Understanding the cytotoxic mechanism of digitoxin and its analogs in NSCLC will help in designing and developing safer and more effective CG-based anti-cancer therapies.

Based on the sensitivity to digitoxin and its analogs [13], and increased resistance to chemotherapy [16], $\mathrm{NCl}-\mathrm{H} 460$ cells were chosen as a NSCLC model in this study. The cytotoxic mechanism of digitoxin and $\alpha$-L-rhamnose digitoxin analog (namely D6-MA) were examined below therapeutically relevant concentrations. We hypothesized that exposure of $\mathrm{NCl}-\mathrm{H} 460$ cells to therapeutically relevant doses of digitoxin and D6-MA would decrease cell viability due to G2/M arrest and induce apoptosis, with greater potency for D6-MA. By comparing cytotoxic mechanisms of digitoxin to D6-MA, we aimed to demonstrate that improved anticancer activity can be obtained by sugar-based modifications of natural products. 


\section{MATERIALS AND METHODS}

Reagents and chemicals

Digitoxin was purchased from Sigma Chemicals (St. Louis, MO). Hoechst 33342, RNase, and propidium iodide (PI) were purchased from Molecular Probes (Eugene, OR). MTT cell viability assay kit, Triton X-100, sodium dodecyl sulfate (SDS), Tris- $\mathrm{HCl}$, EDTA, $\mathrm{NaCl}$, and Complete Mini cocktail protease inhibitors were purchased from Roche Applied Science (Indianapolis, IN). BCA assay kit was purchased from Thermo Scientific (Rockford, IL). Cdc2 antibody was purchased from Santa Cruz Biotechnology (Santa Cruz, CA). All other primary and horseradish peroxidase conjugated secondary antibodies were purchased from Cell Signaling (Boston, MA). Acrylamide/Bis solution was purchased from Bio-Rad Laboratories (Hercules, CA). The iBlot $₫$ dry blotting and transferring system, PVDF transfer membranes, Countess automated cell counter, Countess cell counting chamber slides, and trypan blue stain $0.4 \%$ were purchased from Invitrogen (Carlsbad, CA). High Throughput Colorimetric ATPase Assay kit was purchased from Innova Biosciences Ltd. (Babraham, Cambridge, UK).

Small airway cell basal medium (SABM), SAGM SingleQuots supplementation, and Cabrex medium were purchased from Lonza (Walkersville, MD). Purified $\mathrm{Na}^{+} / \mathrm{K}^{+}$ adenosine 5'-triphosphatase (ATPase) isolated from porcine cerebral cortex, and all other chemicals and reagents (including ethanol, isopropanol, Tween 20, Tris- $\mathrm{HCl}$, DMEM medium, and RPMI 1640 medium) were purchased from Sigma Chemicals (St. Louis, $\mathrm{MO})$. 


\section{Synthesis of D6-MA}

D6-MA, an a-L-rhamnose monosaccharide analog of digitoxin, was synthesized from digitoxin based on a previously described method [12,13]. Briefly, digitoxin was first subjected to acid hydrolysis to cleave off the trisaccharide moiety and generate free aglycone moiety, digitoxigenin (FIGURE 1A). The monosaccharide moiety was then synthesized from $\alpha$-L-pyranose generated from acetyl furan by asymmetric reduction and oxidative rearrangement followed by tert-butoxycarbonyl (BOC) protection of the amino group. Subsequently, a -L-pyranose was conjugated with the digitoxigenin moiety via palladium-catalyzed glycosylation. The resulting digitoxin- $\alpha$-L-pyranose was subjected to Luche reduction to generate digitoxin- $\alpha-L-r h a m n o s i d e$.

\section{Cell culture}

Human NSCLC cells (NCl-H460) and non-tumorigenic human bronchial epithelial cells (BEAS-2B) were purchased from American Type Culture Collection (ATCC, Manassas, VA). Dr. Tom Hei generously provided immortalized small airway epithelial cells (hTERT SAEC) cells. The hTERT SAEC cells were developed and authenticated by the ectopic expression of human telomerase reverse transcriptase (hTERT) in normal human small airway epithelial cells according to the procedure previously described [17]. Primary human respiratory epithelial cells (pSAEC), isolated from the small airway of a normal human donor (Lonza, Walkersville, MD), were also examined. pSAEC were cultured following manufacturer's directions. Electron microscopy and cytokeratin 8 and 18 immunostaining were used to verify the phenotype of the cells. pSAEC were identified as type I and type II lung epithelial cells with a normal diploid human male karyotype. 
Cells of at least $90 \%$ purity and $80 \%$ viability from a single lot were used for all experiments. All cell lines were tested for Mycoplasma contamination using Hoechst fluorescence staining. Briefly, cells were seeded overnight in a 12 well plate at $1 \times 10^{5}$ cells $/ \mathrm{ml}$, stained with $10 \mathrm{mg} / \mathrm{ml}$ of Hoechst 3342 for 30 minutes and analyzed for the presence of foreign or Mycoplasma nuclear material. No Mycoplasma was detected in any of the cell lines tested.

$\mathrm{NCl}-\mathrm{H} 460$ cells were cultured in RPMI 1640 medium supplemented with $10 \%$ bovine fetal serum (FBS), $2 \mathrm{mM} \mathrm{L-glutamine} \mathrm{and} \mathrm{100-units/ml} \mathrm{penicillin/streptomycin.}$ BEAS-2B cells were cultured in DMEM medium supplemented with $5 \%$ bovine fetal serum (FBS), 2 mM L-glutamine and 100-units/ml penicillin/streptomycin. hTERT SAEC cells were cultured in SABM medium supplemented with $1 \%$ bovine serum albumin and SAGM SingleQuots growth factors. Cells were maintained in culture in a humid atmosphere containing $5 \% \mathrm{CO} 2$ at $37^{\circ} \mathrm{C}$. All experiments with $\mathrm{NCl}-\mathrm{H} 460$ and $\mathrm{BEAS}-2 \mathrm{~B}$ cells were performed in medium enriched with 1\% FBS serum, $2 \mathrm{mM} \mathrm{L-glutamine} \mathrm{and}$ 100-units/ml penicillin/streptomycin. 1\% FBS was used due to existing concerns about digitoxin binding to serum proteins $[18,19]$.

\section{Cell viability tests with MTT assay}

Cells were seeded overnight in 96 well plates at a concentration of $1 \times 10^{4}$ cells/well, and then treated for $48 \mathrm{~h}$ with a $\log _{10}$ scale dilution series of either digitoxin or D6-MA dissolved in sterile filtered DMSO. Subsequently, $10 \mathrm{ml}$ of $5 \mathrm{mg} / \mathrm{ml}$ MTT reagent was added to each well and then the wells were incubated for $4 \mathrm{~h}$ at $37^{\circ} \mathrm{C}$. Isopropanol acidified with $0.04 \mathrm{~N} \mathrm{HCl}$ was used to dissolve converted dye. Absorbance at $570 \mathrm{~nm}$ was 
measured using an Automated Microplate Reader ELx800 (BioTek, Winooski, VT). Each experiment was conducted 4 times with 4 replicate wells per concentration.

Trypan blue exclusion assay

$\mathrm{NCl}-\mathrm{H} 460$ cells were seeded overnight in $60 \mathrm{~mm}^{2}$ dishes at $5 \times 10^{5}$ cell/dish, and subsequently treated with $10 \mathrm{nM}$ of either digitoxin or D6-MA for $24 \mathrm{~h}, 48 \mathrm{~h}$ and $72 \mathrm{~h}$. After treatment, cells were collected, stained with $0.4 \%$ trypan blue, and counted using a Countess automated cell counter.

$\mathrm{Na}^{+} / \mathrm{K}^{+}$ATPase activity assay

$\mathrm{Na}^{+} / \mathrm{K}^{+}$ATPase activity assay for release of inorganic phosphate was performed on $\mathrm{Na}^{+} / \mathrm{K}^{+}$ATPase isolated from porcine cerebral cortex following exposure to each compound according to the manufacturer's protocol. Briefly, serial dilutions of each compound were prepared in a buffer containing $50 \mathrm{mM}$ Tris, $25 \mathrm{mM} \mathrm{MgCl} 2,0.5 \mathrm{mM}$ ATP, $130 \mathrm{mM} \mathrm{NaCl}$, and $20 \mathrm{mM} \mathrm{KCl}$ at $\mathrm{pH} 7.5$, then plated in a 96 well plate in triplicate. Subsequently, diluted $\mathrm{Na}^{+} / \mathrm{K}^{+}$ATPase was added to each well and the reaction allowed to proceed for 15 minutes. The reaction was stopped with Pi ColorLock Gold for 30 minutes, and then the absorbance of each well was determined at $595 \mathrm{~nm}$.

Apoptosis assay

Cells were seeded overnight in 12 or 24 well plates at a concentration of $1 \times 10^{5}$ cell/ml and subsequently treated with different concentrations of either digitoxin or D6-MA for $24 \mathrm{~h}$. After treatment, cells were incubated with $10 \mathrm{mg} / \mathrm{ml}$ of Hoechst 33342 for 30 
minutes and analyzed for apoptosis by scoring the percentage of cells having intensely condensed chromatin and/or fragmented nuclei using fluorescence microscopy (Leica Microsystems, Bannockburn, IL). Approximately 1,000 nuclei from ten random fields were analyzed for each sample. The apoptotic index was calculated as the percentage of cells with apoptotic nuclei over total number of cells.

Cell cycle analysis

$\mathrm{NCl}-\mathrm{H} 460$ cells were seeded in $60 \mathrm{~mm}^{2}$ cell culture dishes at a concentration of $5 \times 10^{5}$ cells/dish, starved overnight in serum-free media, and then treated with $1,5,10$, and $20 \mathrm{nM}$ of either digitoxin or D6-MA for $48 \mathrm{~h}$. Treated cells were then trypsinized, collected, washed with PBS and fixed in $70 \%$ ethanol at $4^{\circ} \mathrm{C}$ overnight. Subsequently, cells were washed with PBS and stained with propidium iodide containing $0.05 \%$ RNase. For cell cycle analysis, the DNA content was determined using a FACScan laser flow cytometer (FACSCalibur; Becton Dickinson, San Jose, CA). Data were analyzed using MODFIT software (Verity Software House, Topsham, ME). Experiments were repeated 4 times to conduct statistical analysis.

\section{Western blot analysis}

Cells were seeded in $60 \mathrm{~mm}^{2}$ cell culture dishes at a concentration of $1 \times 10^{6}$ cell/plate, starved overnight, and then treated with 5 to $50 \mathrm{nM}$ of either digitoxin or D6-MA for $24 \mathrm{~h}$. After treatment, cells were collected and lysed for 30 minutes on ice in lysis buffer containing $2 \%$ Triton X-100, $1 \%$ sodium dodecyl sulfate (SDS), $100 \mathrm{mM} \mathrm{NaCl}, 10$ $\mathrm{mM}$, Tris- $\mathrm{HCl}(\mathrm{pH} 7.5), 1 \mathrm{mM}$ EDTA, and Complete Mini cocktail protease inhibitors. 
Insoluble debris was pelleted by centrifugation at $4^{\circ} \mathrm{C}$ and $6800 \mathrm{~g}$ for 15 minutes. Subsequently, the supernatant was collected and used to determine protein content using BCA assay. Briefly, diluted supernatant samples and bovine serum albumin standards were plated in duplicate to a 96 well plate. Working reagent $(1000 \mu \mathrm{L})$ was prepared by mixing 50 parts of reagent $A(1000 \mu \mathrm{L})$ with 1 part of reagent $B(20 \mu \mathrm{L})$, added to each well $\left(200 \mu \mathrm{L}\right.$ each), and incubated at $37^{\circ} \mathrm{C}$ for 30 minutes with $2 \mu \mathrm{L}$ of each protein sample. Absorbance of each well was measured at $562 \mathrm{~nm}$ with a Varioskan spectrophotometer (Thermo, Waltham, MA). BSA protein standard curves were used as standards to determine sample protein content.

Samples were next separated on $12 \%$ SDS-PAGE and transferred to PVDF membranes using the iBlot $₫$ Dry Blotting System. Membranes were blocked in $5 \%$ skim milk in TBST (25 mM Tris- $\mathrm{HCl}, \mathrm{pH} 7.4,125 \mathrm{mM} \mathrm{NaCl}, 0.1 \%$ Tween 20) for $1 \mathrm{~h}$, and subsequently incubated with appropriate primary antibodies at $4^{\circ} \mathrm{C}$ overnight. Membranes were washed three times for 10 minutes each with TBST and then incubated with horseradish peroxidase-conjugated secondary antibodies for $2 \mathrm{~h}$ at room temperature. The immune complexes formed were detected by chemiluminescence (Supersignal West Pico; Pierce, Rockford, IL). Band quantification via densitometry was performed using ImageJ software version 10.2.

\section{Statistical analysis}

All results are presented as mean \pm standard deviation. For cell viability, ATPase activity and apoptosis assays, dose-response curves and concentrations that caused $50 \%$ effect (i.e. $\mathrm{IC}_{50}$ ) were calculated for both digitoxin and D6-MA in all the cell lines 
tested using non-linear regression analysis in GraphPad Prism 5.0 (San Diego, CA). Twoway analysis of variance (ANOVA) and unpaired two-tailed Student's t-test with $\alpha=0.05$ were performed to compare the effect of compounds and administered dose on cell viability, apoptosis and quantified protein expression data. Interactions between variables were tested for and were used as an error term in case they were significant. Post-hoc Tukey-Kramer HSD tests were conducted on significant ANOVA results. Results were considered significant when $p<0.05$.

\section{RESULTS}

D6-MA causes inhibition of $\mathrm{NCl}-\mathrm{H} 460$ cell viability and $\mathrm{Na}^{+} / \mathrm{K}^{+}$ATPase enzyme activity

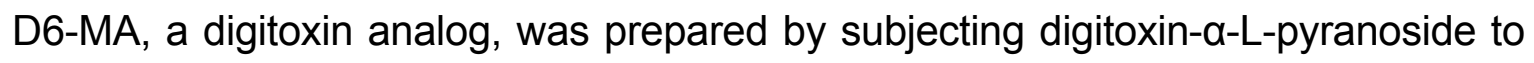
post-glycosylation modification (FIGURE $1 \mathrm{~A}$ ) as previously described $[13,15]$. To evaluate whether D6-MA exhibits greater potency than digitoxin to inhibit $\mathrm{NCl}-\mathrm{H} 460$ cell viability, we performed colorimetric MTT and trypan blue exclusion assays. Non-linear regression analysis (FIGURE 1B) showed that D6-MA exhibited about 4-fold greater potency $\left(\mathrm{IC}_{50}=12.0 \mathrm{nM}\right)$ than digitoxin $\left(\mathrm{IC}_{50}=49.4 \mathrm{nM}\right)$ while Student's t-test detected digitoxin's and D6-MA's inhibition lowest observed effective concentration (LOEC) at 10 $\mathrm{nM}$ and $1 \mathrm{nM}(\mathrm{p}<0.001)$ respectively. Additionally, two-way ANOVA test showed that while both compounds significantly inhibited $\mathrm{NCl}-\mathrm{H} 460$ cell viability in a time dependent manner, D6-MA was significantly more potent than digitoxin (FIGURE 1C; $F=18.11, p$ $<0.0001)$. Next, we tested whether the compounds inhibit $\mathrm{Na}^{+} / \mathrm{K}^{+} \mathrm{ATPase}$ enzyme activity. Non-linear regression analysis showed that $\mathrm{D} 6-\mathrm{MA}$ is more potent $\left(\mathrm{IC}_{50}=1.1 \mu \mathrm{M}\right)$ than digitoxin $\left(I C_{50}=2.8 \mu \mathrm{M}\right)$ at inhibiting activity of isolated $\mathrm{Na}^{+} / \mathrm{K}^{+}$ATPase (FIGURE 1D). 

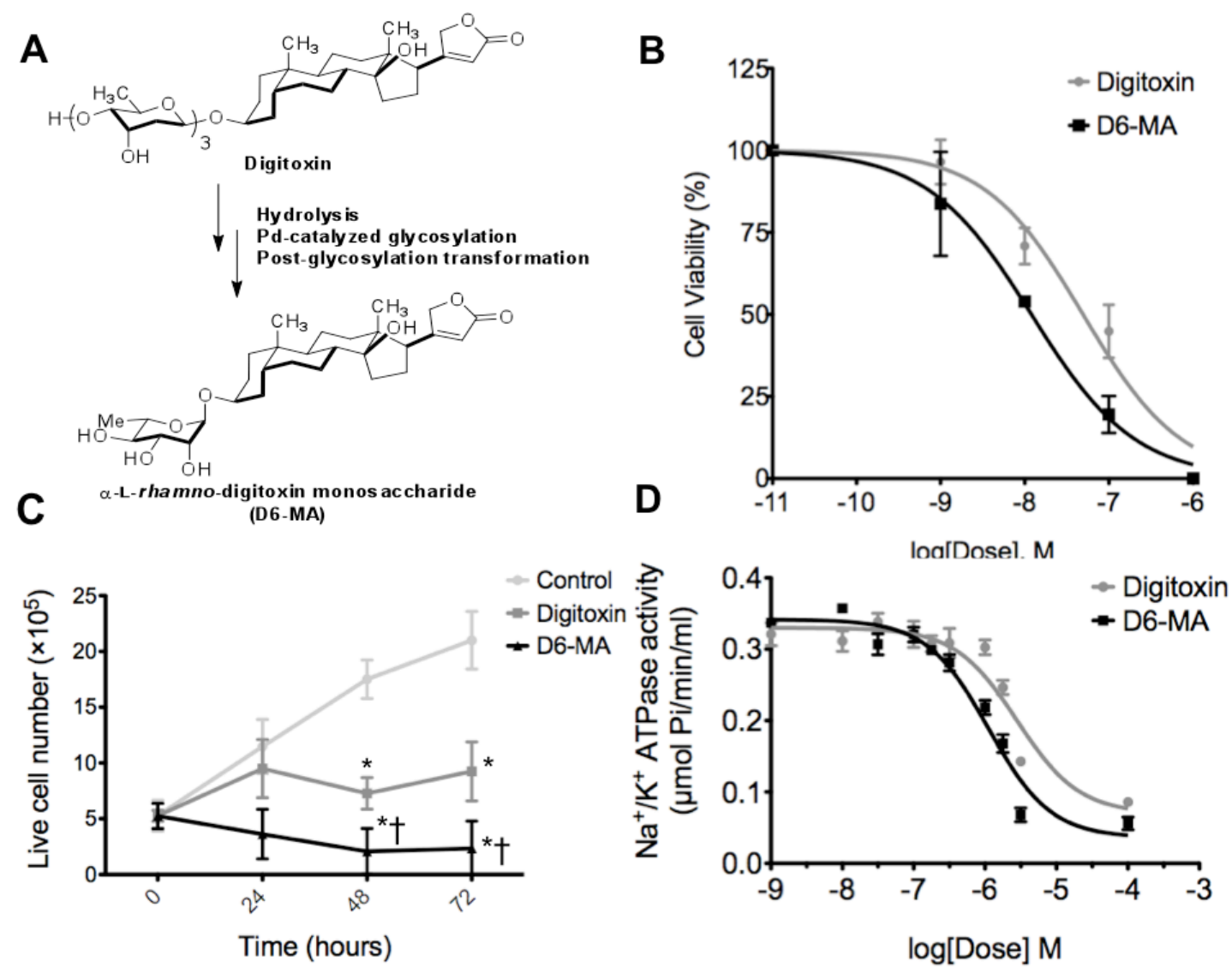

FIGURE 1: Digitoxin and D6-MA inhibit $\mathrm{NCl}-\mathrm{H} 460$ cell viability in a dose dependent manner. (A) $\alpha$-L-rhamnose monosaccharide analog (D6-MA) was synthesized from digitoxin. (B) Dose-response curve showing a 4-fold difference in potency between digitoxin and D6-MA for inhibition of cell viability generated by colorimetric MTT cell viability assay. (C) Time-response inhibition of cell proliferation after treatment with $10 \mathrm{nM}$ of either digitoxin or D6-MA; $\left({ }^{*}\right)$ indicates significantly different from control, $(\dagger)$ indicates significantly different from digitoxin. (D) Dose-response inhibition of $\mathrm{Na}^{+} / \mathrm{K}^{+} A T P a s e$ activity.

\section{D6-MA induces apoptosis in NCl-H460 cells}

Previous studies attributed the anti-neoplastic effects of CG to their capacity to induce apoptosis [3]. To investigate whether D6-MA is more potent than digitoxin in inducing apoptosis, we exposed $\mathrm{NCl}-\mathrm{H} 460$ cells to each of the compounds and used Hoechst 33342 DNA fragmentation assay to evaluate the apoptotic effects. Non-linear regression analysis showed that the percentage of $\mathrm{NCl}-\mathrm{H} 460$ cells displaying apoptotic 
nuclei was both dose and compound dependent (FIGURE 2A and 2B), with D6-MA displaying about 5-fold greater potency $\left(\mathrm{IC}_{50}=10 \mathrm{nM}\right)$ when compared to digitoxin $\left(\mathrm{IC}_{50}=\right.$ $48 \mathrm{nM})$.

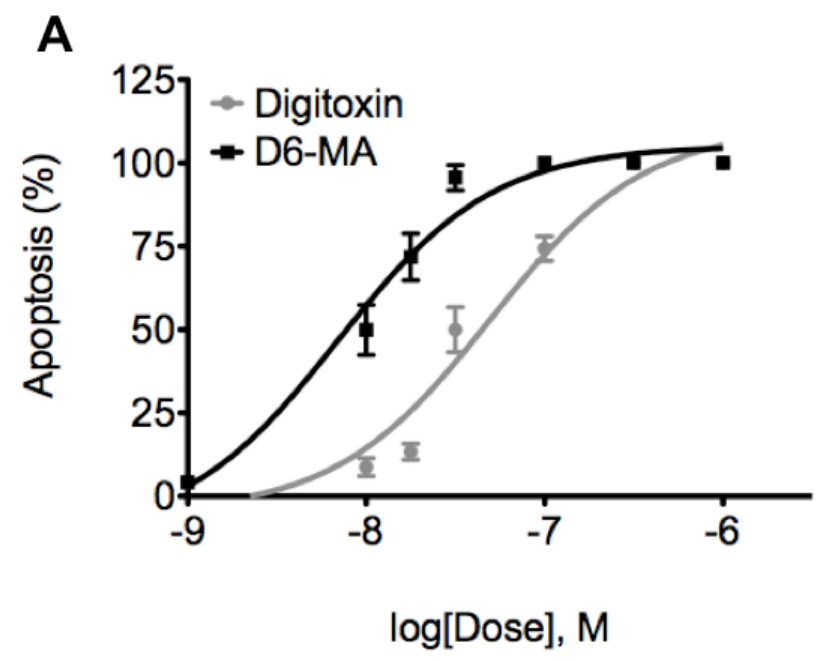

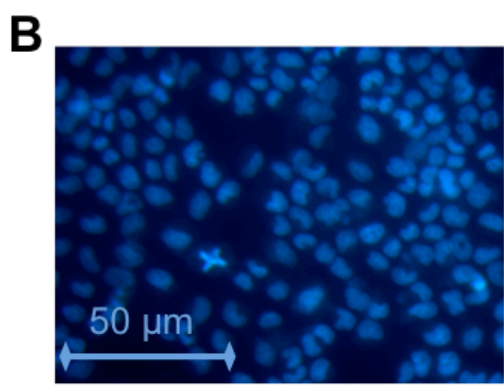

$0 \mathrm{nM}$

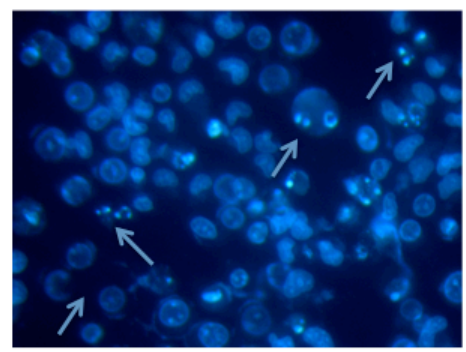

Digitoxin $50 \mathrm{nM}$

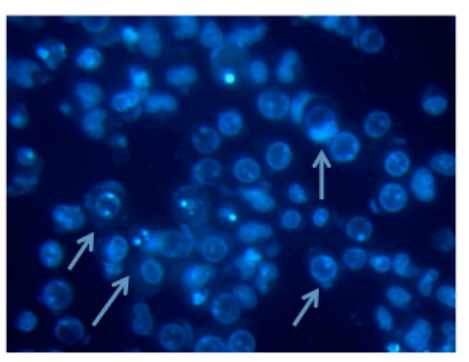

D6-MA $10 \mathrm{nM}$

FIGURE 2: Digitoxin and D6-MA induce $\mathrm{NCl}-\mathrm{H} 460$ cell apoptosis in a dose dependent manner. (A) Dose-response induced apoptosis. (B) Hoechst staining and fluorescence microscopy images of $\mathrm{NCl}-\mathrm{H} 460$ cells. Arrows point to apoptotic cells.

D6-MA exhibits selective cytotoxicity to NSCLC cells

Anti-cancer drugs ought to be selectively toxic toward cancer cells and not normal cells. To test whether digitoxin and D6-MA are selectively toxic to NSCLC cells, we exposed primary small airway epithelial cells (pSAEC), immortalized non-tumorigenic human small airway epithelial cells (hTERT SAEC), and immortalized non-tumorigenic 
human bronchial epithelial cells (BEAS-2B) to digitoxin and D6-MA, and used Hoechst 33342 DNA fragmentation assay to evaluate apoptosis in these cell lines. Interestingly, non-linear regression analysis showed that treated hTERT SAEC and BEAS-2B cells had significantly less sensitivity to apoptosis for either of the compounds when compared to $\mathrm{NCl}-\mathrm{H} 460$ cells (FIGURE $3 \mathrm{~A}$ and $\mathrm{B}$ ).
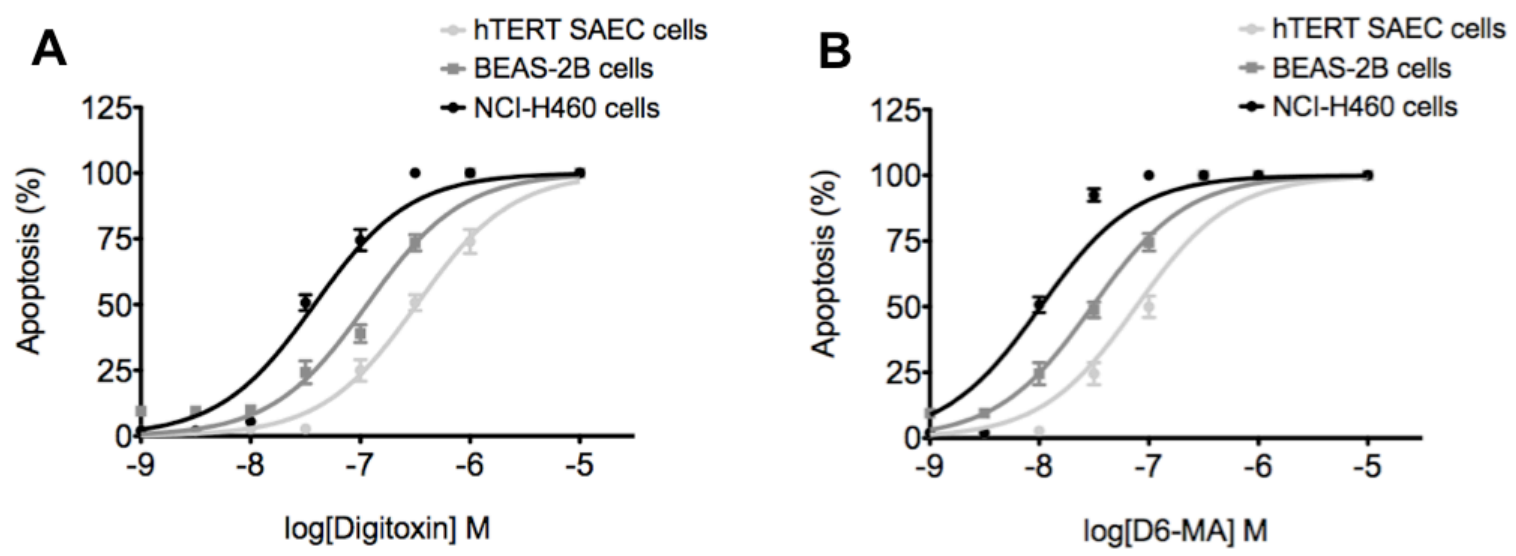

C

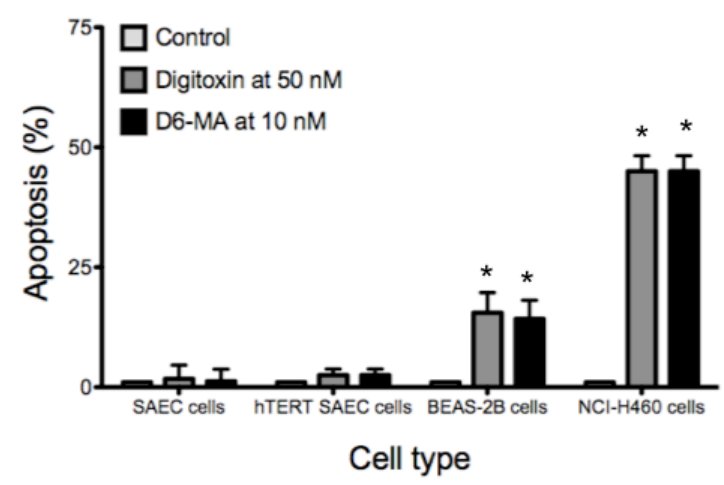

D

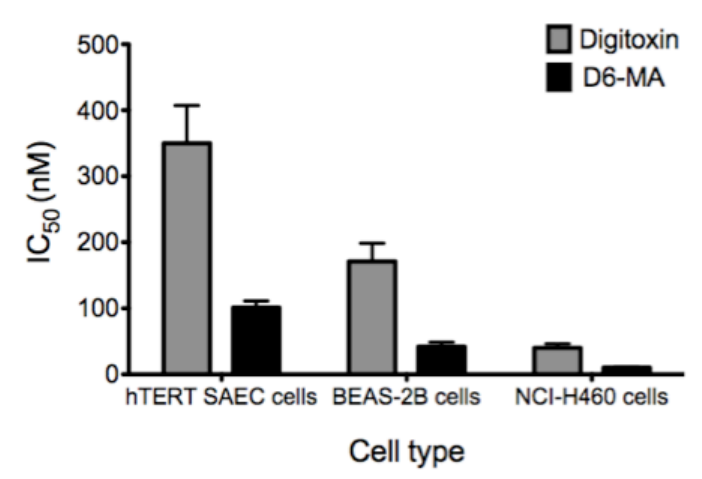

FIGURE 3: The apoptotic effect of digitoxin and D6-MA is selective to non-small cell lung cancer cells. (A) Digitoxin dose-response in hTERT SAEC, BEAS-2B, and NCIH460 cells. (B) D6-MA dose-response in hTERT SAEC, BEAS-2B, and NCl-H460 cells. (C) Nontumorigenic hTERT SAEC cells and BEAS-2B cells have higher $\mathrm{IC}_{50}$ values than $\mathrm{NCl}$ $\mathrm{H} 460$ cells. Error bars represent $\mathrm{IC}_{50}$ values at $95 \%$ confidence intervals. (D) Primary SAEC cells, non-tumorigenic hTERT SAEC cells, and BEAS-2B cells are less sensitive to apoptosis for either digitoxin $(50 \mathrm{nM})$ or D6-MA (10 nM). Error bars represent standard deviation; $\left(^{*}\right)$ indicates significantly different from untreated cells. 
To validate this finding, an apoptosis assay with set doses of digitoxin and D6-MA on all four cell lines was conducted. Two-way ANOVA showed a significant difference between cell line sensitivity (FIGURE 3C; $F=91.84, p<0.0001$ ) while no difference existed between the compounds with dosing placed at a 5-fold interval. Specifically, $\mathrm{NCl}-\mathrm{H} 460$ and BEAS-2B cells showed greater sensitivity to each compound while both SAEC cell lines displayed minimal sensitivity. In addition, D6-MA exhibited a 4-fold greater potency than digitoxin to induce apoptosis regardless of cell type (FIGURE 3D).

D6-MA induces expression of cytochrome $c$ and extensive caspase9 cleavage

Previous studies have shown that sequential activation of caspases and increased cytochrome c expression play a central role in the execution phase of apoptosis [20]. Specifically, caspase8 and caspase9 mediate the extrinsic (death ligand) and intrinsic (mitochondrial) apoptotic pathways, respectively. Studies have also shown that caspase3 interacts with both caspase 8 and -9 and experiences activation in both apoptotic signaling pathways [20]. With persistent apoptotic stimulus, increased cytochrome c is released from mitochondria into the cytoplasm, recruits pro-caspase 9 and APAF1 and forms the apoptosome that causes caspas9 activation [20]. 

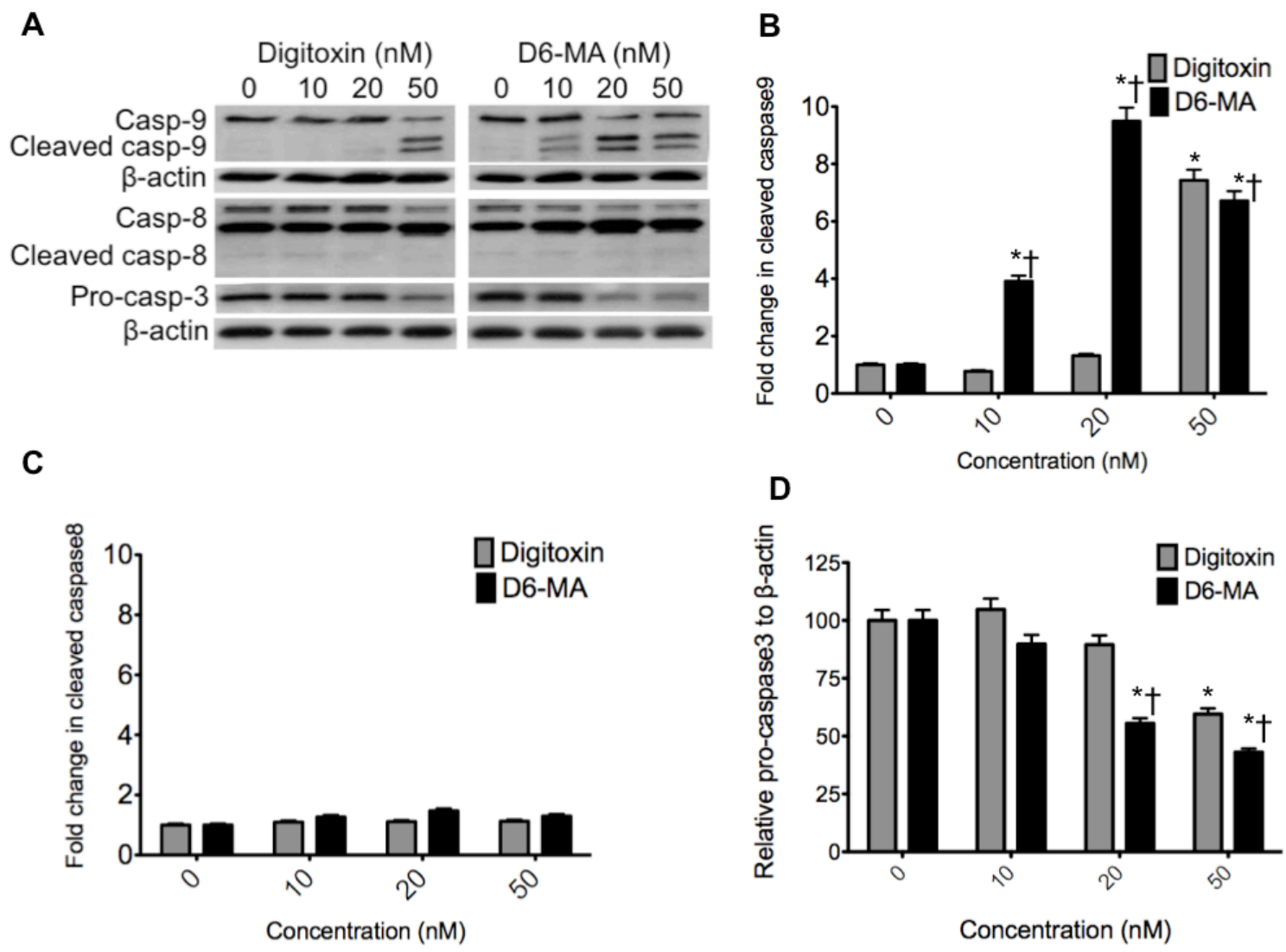

FIGURE 4: Western blot analysis show changes in caspase9, 8, and 3. (A) Digitoxin and D6-MA induced differential cleavage of caspase9. Digitoxin caused pro-caspase 3 to drop at $50 \mathrm{nM}$, while D6-MA caused pro-caspase 3 to drop at $20 \mathrm{nM}$. (B) Quantification of cleaved caspase9 blots shows fold change in cleavage following treatment. (C) Quantification of cleaved caspase8 blots shows fold change in cleavage following treatment. (D) Quantification of pro-caspase 3 blots shows decrease in quantity following treatment; $\left({ }^{*}\right)$ indicates significantly different from control, $(\dagger)$ indicates significantly different from digitoxin.

To examine which apoptotic pathway predominates in $\mathrm{NCl}-\mathrm{H} 460$ cells exposed to digitoxin or D6-MA, we performed Western blot analysis for cytochrome c and caspase cleavage respectively. Based on $\beta$-actin expression (used as control), two-way ANOVA with subsequent post-hoc tests showed that D6-MA exhibited greater potency than digitoxin in inducing substantial caspase9 cleavage (FIGURE 4A, and 4B; F=28.78, 
$p<0.0001)$. Pro-caspase 3 experienced a significant drop in expression (FIGURE 4A, and 4C; $F=7.19, p<0.0001$ ) while caspase8 displayed slight cleavage following digitoxin and D6-MA treatment (FIGURE 4A, and 4D; $F=16.06, p=0.066$ ).

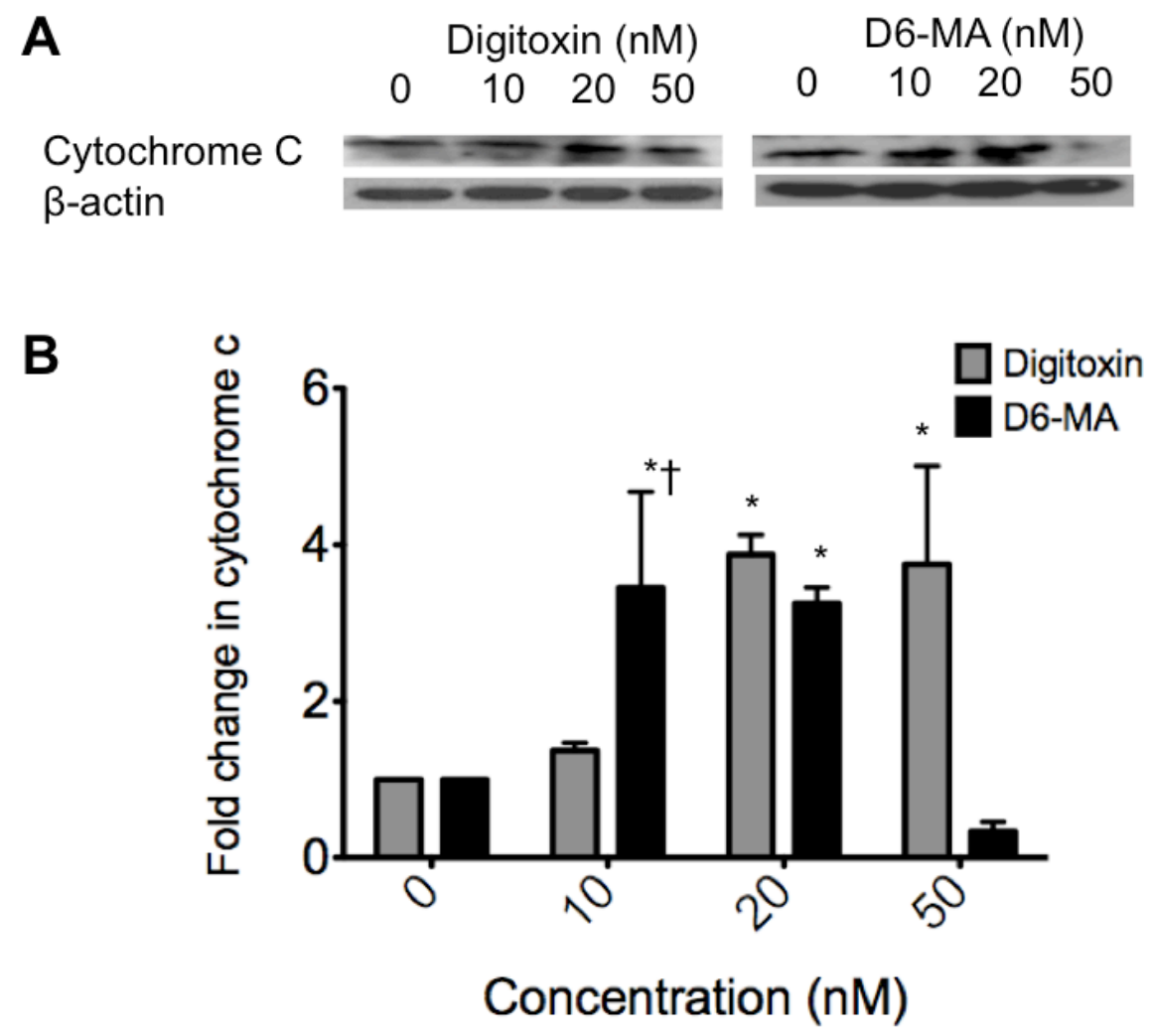

FIGURE 5: Western blot analysis shows changes in cytochrome c expression. (A) Digitoxin and D6-MA induce cytochrome $c$ expression in a dose dependent manner. (B) D6-MA is more potent than digitoxin in inducing cytochrome c expression ( $F=25.51$, $p<0.001)$. Quantification of cytochrome c blots shows increased expression following treatment $\left({ }^{*} \mathrm{p}<0.05\right.$ compared $0 \mathrm{nM}, \uparrow \mathrm{p}<0.05$ compared to digitoxin treatment).

Additionally, two-way ANOVA and post-hoc testing showed that D6-MA was more potent than digitoxin in inducing cytochrome c expression (FIGURE 5A) at $10 \mathrm{nM}$ while at $50 \mathrm{nM}$, D6-MA significantly reduced cytochrome c expression (FIGURE 5B; F=25.52, $p<0.001)$. 
Digitoxin and D6-MA induce G2/M phase arrest

Previous research suggested that cell cycle arrest causes apoptosis or loss of cell viability $[2,21]$. To investigate whether digitoxin or D6-MA induces cell cycle arrest, we exposed $\mathrm{NCl}-\mathrm{H} 460$ cells to different doses of either digitoxin or D6-MA for $48 \mathrm{~h}$. Using two-way ANOVA our results showed that digitoxin and D6-MA significantly increased the percentage of cells in sub-G1 phase in a dose dependent manner (FIGURE 6A and FIGURE 6B; $F=16.1, p<0.0001)$.

A

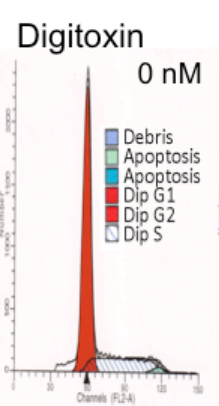

D6-MA
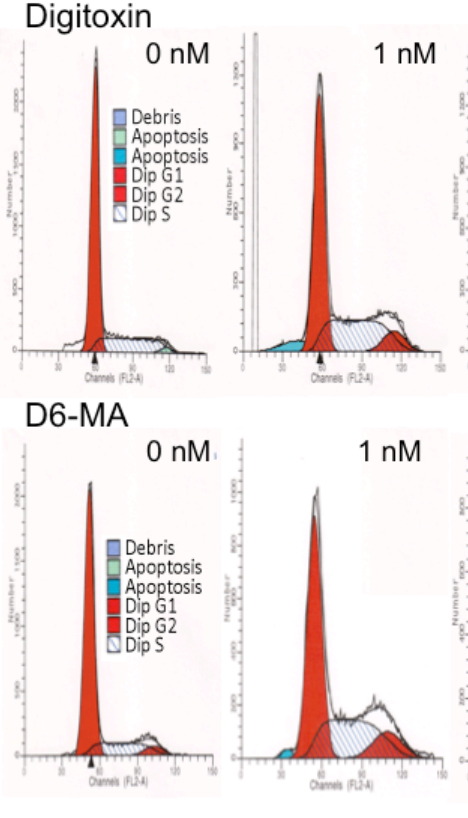

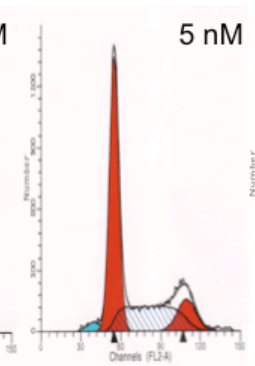

$5 \mathrm{nM}$
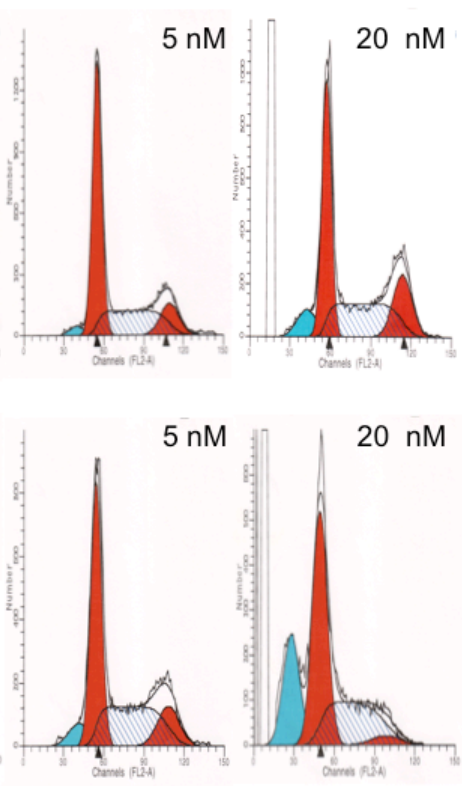

B

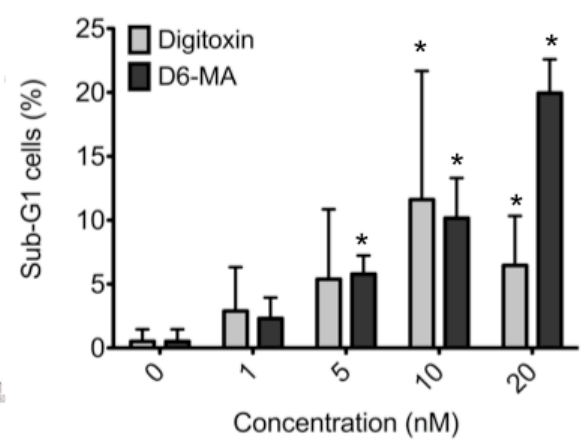

C

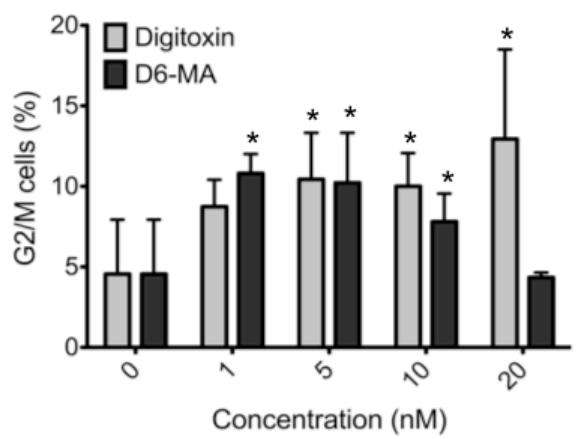

FIGURE 6: Digitoxin and D6-MA induce G2/M arrest in NCl-H460 cells. (A) Digitoxin and D6-MA induced an increase in the G2/M and sub-G1 cell populations. (B) Digitoxin and D6-MA pushed cells into sub-G1 phase. (C) Digitoxin and D6-MA induced significant G2/M phase arrest compared to controls; $\left({ }^{*}\right)$ indicates significantly different from control, $(\dagger)$ indicates significantly different from digitoxin, $p<0.05)$. 
Additionally, D6-MA was significantly more potent than digitoxin at $20 \mathrm{nM}$ (FIGURE 6B; $p=0.0071$ ). Both compounds induced $G 2 / M$ arrest and in a dose-dependent manner (FIGURE 6A and FIGURE 6C; $p=0.0099$ ). D6-MA's LOEC for inducing G2/M phase arrest was at $1 \mathrm{nM}$, while digitoxin showed comparable effect at $5 \mathrm{nM}$. Moreover, digitoxin increased G2/M phase arrest in a dose dependent manner, while D6-MA G2/M phase arrest peaked between 1 and $5 \mathrm{nM}$ and then decreased to control levels at $20 \mathrm{nM}$.

Our results suggest that the drop in the percentage of D6-MA-treated cells in G2/M phase coincide with a significant increase of cells in sub-G1 phase.

Digitoxin and D6-MA induce down-regulation of cyclin B, cdc2, and survivin

Inducing G2/M phase arrest usually occurs following an alteration in the signaling pathways that control cell progression through G2/M phase [22]. Since our results showed that the percentage of cells in G2/M phase increased upon exposure to digitoxin and D6-MA, we further investigated how digitoxin and D6-MA induce G2/M phase arrest. Specifically, we examined the expression of key molecular drivers of G2/M phase, namely cyclinB1, cdc2, and survivin, using Western blot analysis. Cdc2 requires both cdc2 and cyclinB1 in the complex form for adequate activity. CyclinB1/cdc2 complex is known to catalyze the chromatin condensation as well as nuclear envelope breakdown during mitosis, thus performing a key and rate limiting function in the cell transition from $\mathrm{G} 2$ to $\mathrm{M}$ phase [22]. Survivin promotes mitosis by activating the chromosomal passenger complex [23]. Moreover, the phosphorylation of survivin by cyclinB1/cdc2 complex facilitates the association of survivin/caspase9, which inhibits caspase9 activity [24]. Two-way ANOVA testing revealed that D6-MA was significantly more potent than digitoxin in inducing dose- 
dependent down regulation of cyclinB1, cdc2, and survivin (FIGURE 7A-E; F= 29.06, 6.8, and 25.43; $p<0.0001,0.0036$, and 0.0001 respectively) based on $\beta$-actin and GAPDH expression.).

A
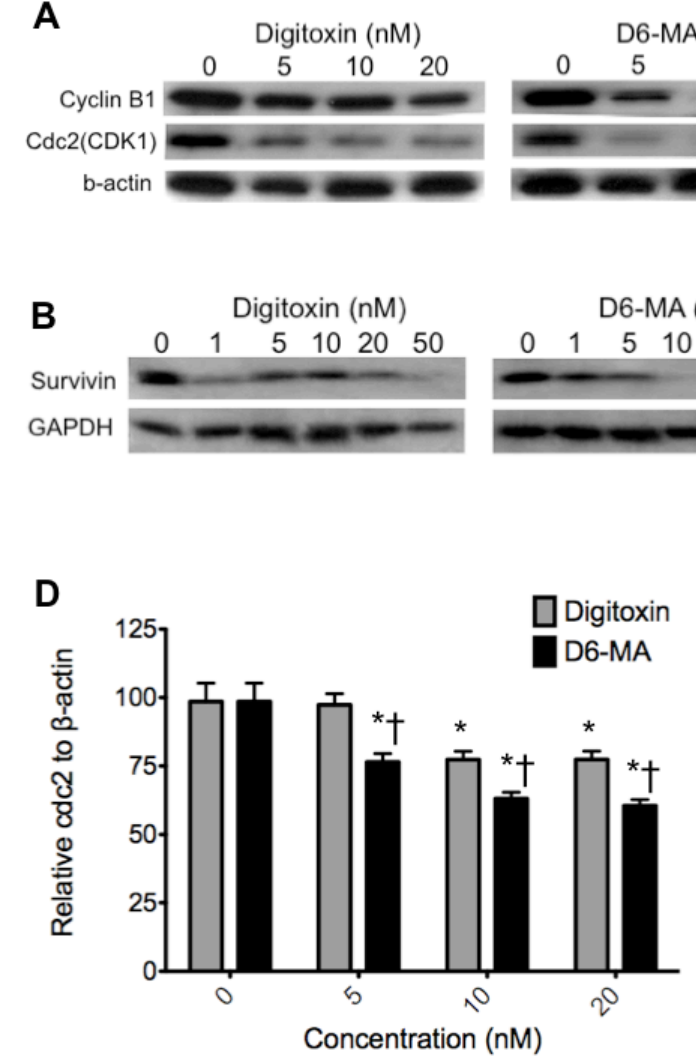

C
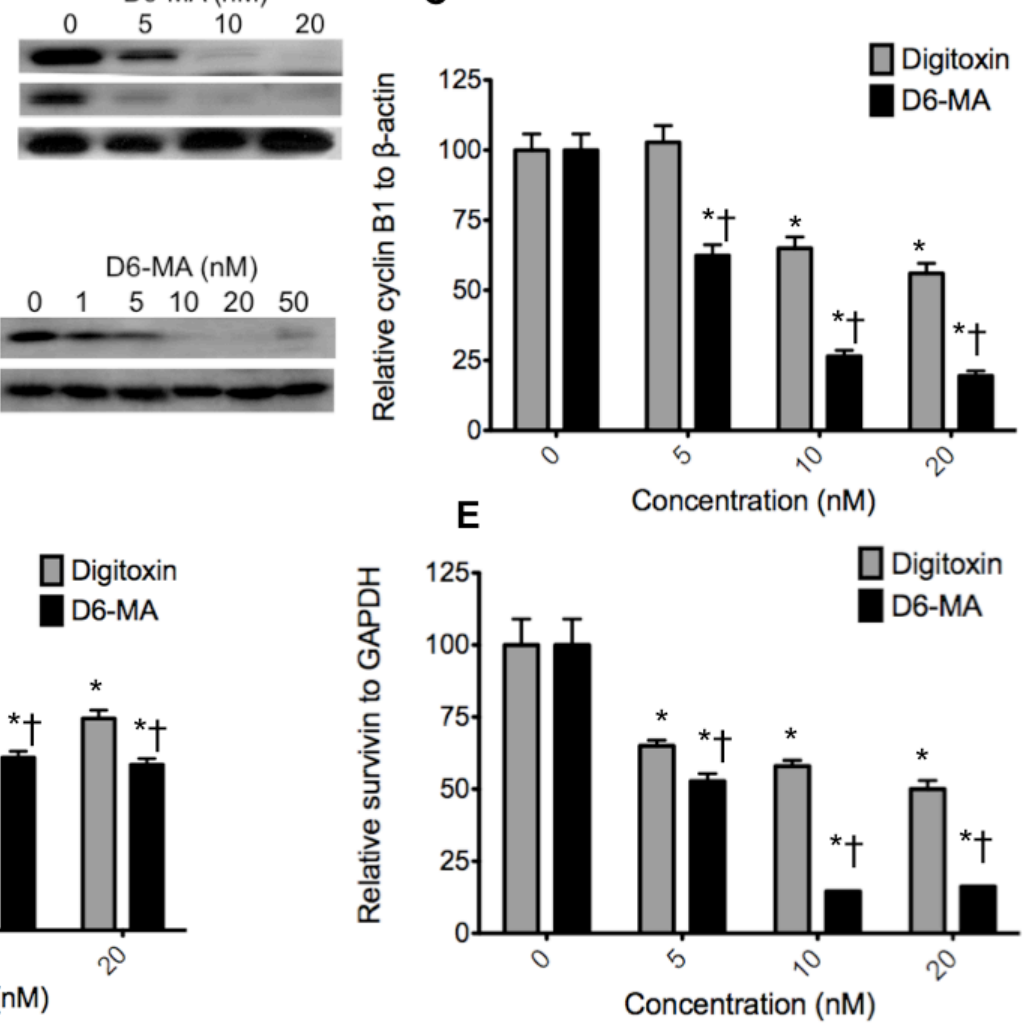

FIGURE 7: Western blot analysis show decreased expression of cyclinB1, cdc2, and survivin. (A) Digitoxin and D6-MA inhibited cyclinB1 and cdc2 expression in a dose dependent manner. (B) Digitoxin and D6-MA inhibited survivin expression in a dose dependent manner. (C) D6-MA is more potent than digitoxin in inhibiting cyclinB1 expression $(F=29.06, p<0.001)$. Quantification of cyclinB1 blots shows decreased expression following treatment $\left({ }^{*} p<0.05\right.$ compared $0 \mathrm{nM},+p<0.05$ compared to respective digitoxin treatment). (D) D6-MA is more potent than digitoxin in inhibiting cdc2 expression $(F=6.805, p=0.0036)$. Quantification of cdc2 blots shows decreased expression following treatment ( ${ }^{*} p<0.05$ compared $0 \mathrm{nM}, \uparrow p<0.05$ compared to respective digitoxin treatment). (E) D6-MA is more potent than digitoxin in inhibiting survivin expression ( $F=25.43$, $p<0.001$ ). Quantification of survivin blots shows decreased expression following treatment ( ${ }^{*} \mathrm{p}<0.05$ compared $0 \mathrm{nM},+\mathrm{p}<0.05$ compared to respective digitoxin treatment). 
D6-MA's LOEC for reducing expression of both cyclin B and cdc2 was $5 \mathrm{nM}$ while digitoxin showed similar effect at $10 \mathrm{nM}$ (FIGURE 7C and D). Both compounds exhibited reduced survivin expression LOEC at $5 \mathrm{nM}$ (FIGURE 7E). Interestingly, the doses that resulted in reduced expression of each protein correlated with the observed arrest in G2/M phase; moreover, this was dependent on compound treatment, thus implicating these proteins in cell cycle arrest signaling.

Digitoxin and D6-MA-mediated G2/M phase arrest does not correlate with up-regulation of p53-related signaling protein or Chk1/2

We further aimed to identify the signaling pathways that mediate G2/M phase arrest following exposure to digitoxin or D6-MA. For this we examined the key upstream regulatory pathways of the cyclinB1/cdc2 complex. Since p53 functions as a key coordinator of cell cycle check point activity and as an effective promoter of apoptosis [22, 25], we also examined p53-related signaling including p53, p21, and p27 [25]. Our results showed that while digitoxin significantly inhibited the expression of p53, p21, and p27 at concentrations between 5 to $20 \mathrm{nM}$, D6-MA was significantly more potent in inducing down-regulation of p53, p21, and p27 (FIGURE 8A). Specifically, two-way ANOVA and post-hoc testing confirmed that p53, p21 and p27 expression was compound and dose dependent (FIGURE 8B-D; $F=52.89,2.06$, and 4.23; $p<0.001,0.0008$, and 0.0155 respectively). 

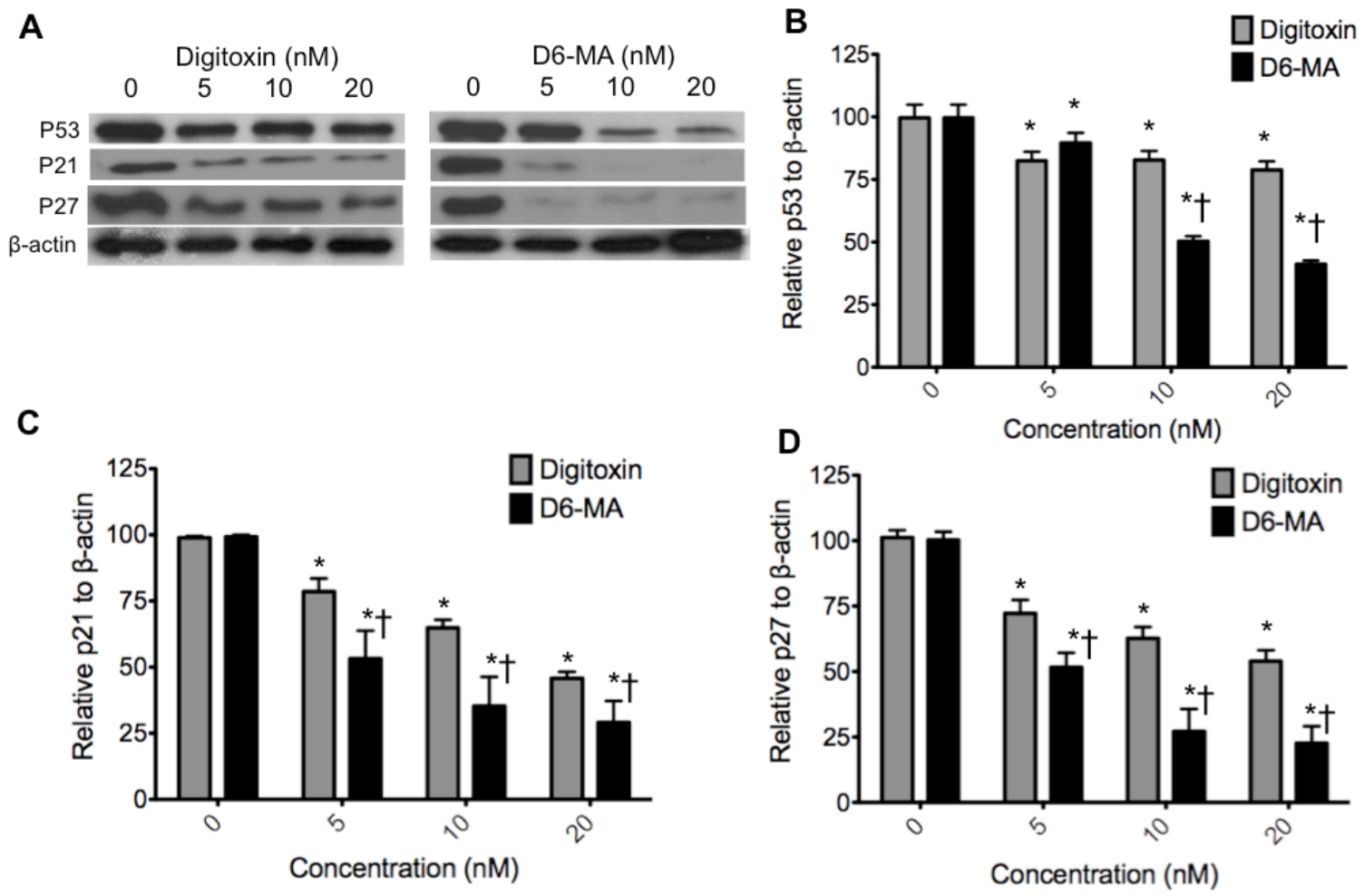

FIGURE 8: Western blot analysis show decreased expression of p53, p21, and p27. (A) Digitoxin and D6-MA down-regulated p53, p21, and p27 in a dose dependent manner. (B) D6-MA is more potent than digitoxin in inhibiting p53 expression $(F=52.89, p<0.001)$. Quantification of $p 53$ blots shows decreased expression following treatment $\left({ }^{*} p<0.05\right.$ compared $0 \mathrm{nM}, \uparrow p<0.05$ compared to respective digitoxin treatment). (C) D6-MA is more potent than digitoxin in inhibiting p21 expression $(F=4.23, p<0.001)$. Quantification of p21 blots shows decreased expression following treatment ( ${ }^{*} p<0.05$ compared $0 \mathrm{nM},+p<0.05$ compared to respective digitoxin treatment). (D) D6-MA is more potent than digitoxin in inhibiting p27 expression ( $F=2.06, p=0.008)$. Quantification of $p 27$ blots shows decreased expression following treatment $\left({ }^{*} p<0.05\right.$ compared $0 \mathrm{nM},+p<0.05$ compared to respective digitoxin treatment).

We also examined whether checkpoint kinase 1 and 2 (Chk1/2) up-regulation contributed to $\mathrm{G} 2 / \mathrm{M}$ phase arrest signaling. Chk1/2 is involved in DNA damage response and in normal cell cycle progression by controlling cell cycle checkpoints [26-28]. Our results and two-way ANOVA analysis showed that digitoxin and D6-MA induced inhibition of Chk1 and Chk 2 expression and was dose-dependent (FIGURE 9A-C; F = 36.11 and 
7.982; $p<0.001$ and 0.002 respectively). Notably, Chk1 experienced a 2 -fold decrease in expression while Chk2 exhibited a less substantial decrease. Reduced expression of both proteins correlated with similar trends observed with cyclin B and cdc2.
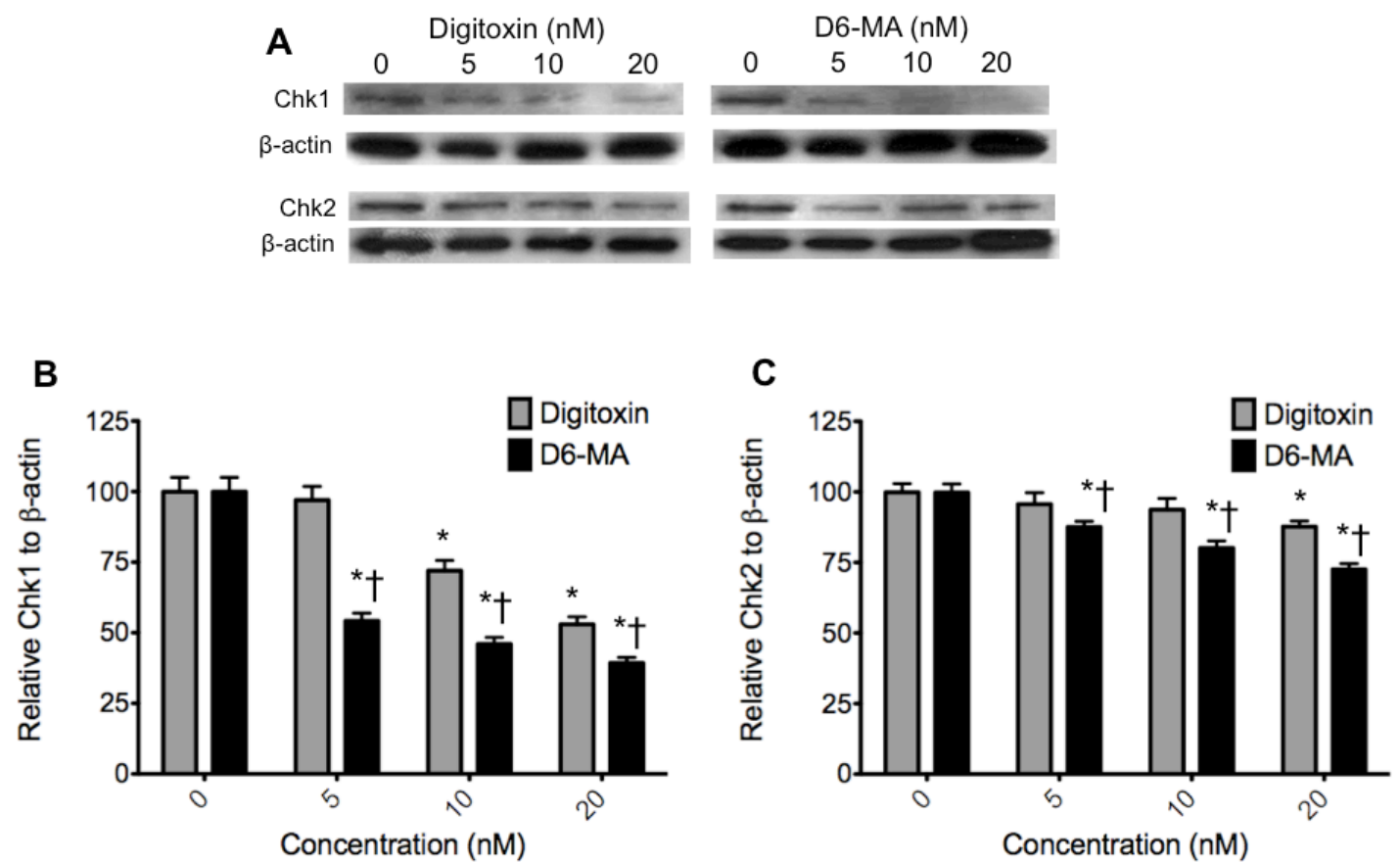

FIGURE 9: Western blot analysis show decreased expression of Chk1 and Chk2. (A) Digitoxin and D6-MA down-regulated Chk1 and Chk2 in a dose dependent manner. (B) D6-MA is more potent than digitoxin in inhibiting Chk1 expression $(F=10.17, p<0.001)$. Quantification of Chk1 blots shows decreased expression following treatment $\left({ }^{*} \mathrm{p}<0.05\right.$ compared $0 \mathrm{nM}, \uparrow p<0.05$ compared to respective digitoxin treatment). (C) D6-MA is more potent than digitoxin in inhibiting Chk2 expression ( $F=7.982, p<0.001)$. Quantification of Chk2 blots shows decreased expression following treatment ( ${ }^{*} p<0.05$ compared $0 \mathrm{nM}$, $\mathrm{tp}<0.05$ compared to respective digitoxin treatment).

\section{DISCUSSION}

Our study aimed to evaluate and compare the cytotoxic potency of digitoxin and D6-MA in $\mathrm{NCl}-\mathrm{H} 460$ cells in order to derive the mechanisms and signaling pathways responsible for cell cycle arrest. Such studies could lead to feasible, reliable and more 
potent drug therapies, which exhibit potent anti-cancer effects at safe and therapeutically relevant doses. Our results showed that digitoxin and D6-MA modulates one or several signaling pathways controlling cell cycle progression, cell proliferation, and apoptosis.

Cardiac glycosides (CGs) are known to mediate their cellular effects by inhibiting the $\mathrm{Na}^{+} / \mathrm{K}^{+}$ATPase activity, by affecting ion homeostasis at high doses and activating the ATPase signalosome at low doses [3, 29]. Our studies showed that D6-MA is more potent than digitoxin at inhibiting $\mathrm{Na}^{+} / \mathrm{K}^{+}$ATPase activity. Interestingly, concentrations of digitoxin and D6-MA that inhibited $\mathrm{Na}^{+} / \mathrm{K}^{+}$ATPase activity were more than 10 -fold greater than their cytotoxic concentrations. This result suggests that $\mathrm{Na}^{+} / \mathrm{K}^{+}$ATPase inhibition by either digitoxin or D6-MA does not account for drug or analog cytotoxic effects, thus leaving the possibility for signalosome activation.

We hypothesized that the apoptotic effect of digitoxin and D6-MA are selective to NSCLC cells. To test this hypothesis, we performed Hoechst apoptosis assay on primary human lung epithelial cells and non-tumorigenic human lung epithelial cells treated with each compound. Our results showed that D6-MA caused increased apoptosis when compared to digitoxin in all the cell lines being tested. Moreover, digitoxin and D6-MA showed higher $\mathrm{IC}_{50}$ values in non-tumorigenic lung epithelial cells than in NSCLC cells. Thus, this confirmed that primary human lung epithelial cells and non-tumorigenic human lung epithelial cells are significantly less sensitive to digitoxin and D6-MA when compared to $\mathrm{NCl}-\mathrm{H} 460$ cells.

We further hypothesized that for both digitoxin and D6-MA, apoptosis is mediated through the mitochondrial pathway. Mitochondrial pathway involvement leads to cytochrome c release and association with pro-caspase 9 and APAF-1 respectively [20]. 
Such association leads to caspase 9 and caspase 3 activation and induced cell apoptosis [20]. To test this hypothesis, we performed Western blot analysis of $\mathrm{NCl}-\mathrm{H} 460$ cells exposed to digitoxin and D6-MA, respectively. Our results showed that D6-MA was more potent than digitoxin in inducing cytochrome c expression and cleavage of caspase9, while for pro-caspase 3 there was a drop in expression and only slight differential cleavage for caspase8. In addition, increased cytochrome c expression suggests that H460 cells retained their ability to synthesize protein, which contrasts previous claims that CG induced cytotoxicity is due to general inhibition of protein synthesis [30].

We further investigated cyclinB1 and cdc2 regulation; cyclinB1 and cdc2 form cyclinB1/cdc2 complex that is crucial for progression of cells through G2/M phase, protects mitotic cells from apoptosis, and maintains cancer cell viability [22, 31, 32]. We showed down-regulation of cyclinB1 and cdc2 by both digitoxin and D6-MA, with D6-MA exhibiting greater potency in reducing cell viability.

We also tested whether survivin, a protein that promotes mitosis by activating the chromosomal passenger complex [23] is involved in the reduced $\mathrm{NCl}-\mathrm{H} 460$ cell viability. Our results showed that digitoxin and D6-MA induced survivin down-regulation at subtherapeutic concentrations, with D6-MA being significantly more potent than digitoxin. Such down-regulation further explains the observed G2/M phase arrest and points to survivin as being a viable target for digitoxin or D6-MA mediated anti-neoplastic activity in $\mathrm{NCl}-\mathrm{H} 460$ cells.

Our results provide further support that cytotoxic effects of CGs are independent of p53 status. Digitoxin's ability to down-regulate p53, even though is first demonstrated in this study, is supported by previous reports employing other CGs (such as ouabain and 
digoxin) in both breast and lung cancer cells [33, 34]. For instance, p53 null and p53 wild type lung cancer cells were previously shown to exhibit equal cell death when exposed to CGs [34]. In addition, we also report for the first time on the down-regulation of p21 and p27 by digitoxin and D6-MA. Several studies suggested that p21 possesses oncogenic properties in promoting mitosis and cell migration [35-37]. In contrast to our findings, p21 up-regulation in breast cancer cells following ouabain exposure was reported [33]. p21 down-regulation possibly explains the reduced $\mathrm{NCl}-\mathrm{H} 460$ cell viability following digitoxin and D6-MA exposure.

We also studied Chk1/2 expression to further explain the reduced cell viability associated with G2/M arrest. Chk1/2 is known to mediate cell cycle arrest following DNA damage or stress response $[27,28,38]$. Abrogating cell cycle checkpoints by chemotherapeutic agents that specifically target Chk1/2 was shown to be an effective chemotherapeutic alternative for several types of cancer [27, 28, 38]. We are first to show that digitoxin and D6-MA inhibit Chk1/2 expression at sub-therapeutic concentrations in $\mathrm{NCl}-\mathrm{H} 460$ cells, with the D6-MA being more potent than digitoxin. These results indicate that following digitoxin or D6-MA treatment neither G2/M phase arrest, nor downregulation of cyclinB1 and cdc2 is mediated by the up-regulation of Chk1/2. However, down-regulation of Chk1/2 following treatment with digitoxin or D6-MA at sub-therapeutic concentrations can explain the reduced cell viability found in our studies.

The results presented herein further advance our understanding of the selective anti-neoplastic mechanism of sub-therapeutic digitoxin concentrations towards NSCLC cancer cells. In addition, enhanced and selective anti-neoplastic activity of D6-MA for 
NSCLC opens new perspectives for more effective chemotherapeutic strategies based on artificially synthesized compounds.

\section{CONCLUSIONS}

This study is the first to focus on determining anti-neoplastic effects of realistic, subtherapeutic doses of digitoxin and D6-MA in $\mathrm{NCl}-\mathrm{H} 460$ cancer cells. We show for the first time that sub-therapeutic concentrations of digitoxin and D6-MA induce G2/M phase arrest and cyclinB1 and cdc2 down-regulation, with D6-MA exhibiting greater potency than digitoxin. Our results also suggest that G2/M phase arrest and down regulation of cyclinB1 and cdc2 by digitoxin and D6-MA are not directly controlled by up-regulation of p53 signaling or checkpoint kinase signaling.

\section{REFERENCES}

1. Lapenna S, Giordano A: Cell cycle kinases as therapeutic targets for cancer. Nat Rev Drug Discov 2009, 8(7):547-566.

2. Schwartz GK, Shah MA: Targeting the Cell Cycle: A New Approach to Cancer Therapy. Journal of Clinical Oncology 2005, 23(36):9408-9421.

3. Newman RA, Yang P, Pawlus AD, Block Kl: Cardiac Glycosides as Novel Cancer Therapeutic Agents. Molecular Interventions 2008, 8(1):36-49.

4. Daniel D, Süsal C, Kopp B, Opelz G, Terness P: Apoptosis-mediated selective killing of malignant cells by cardiac steroids: maintenance of cytotoxicity and loss of cardiac activity of chemically modified derivatives. Int Immunopharmacol 2003, 3(13-14):1791-1801. 
5. Lawrence TS: Ouabain sensitizes tumor cells but not normal cells to radiation. Int J Radiat Oncol Biol Phys 1988, 15(4):953-958.

6. López-Lázaro M: Digitoxin as an anticancer agent with selectivity for cancer cells: possible mechanisms involved. Expert Opin Ther Targets 2007, 11(8):1043-1053.

7. Lopez-Lazaro M, Pastor N, Azrak SS, Ayuso MJ, Austin CA, Cortes F: Digitoxin inhibits the growth of cancer cell lines at concentrations commonly found in cardiac patients. J Nat Prod 2005, 68(11):1642-1645.

8. Stenkvist B: Cardiac glycosides and breast cancer, revisited. N Engl J Med 1982, 306:484.

9. Xie Z, Cai T: Na+/K+ATPase-Mediated Signal Transduction: From Protein Interaction to Cellular Function. Molecular Interventions 2003, 3(3):157-168.

10. Iyer AKV, Zhou M, Azad N, Elbaz H, Wang L, Rogalsky DK, Rojanasakul Y, O'Doherty GA, Langenhan JM: A Direct Comparison of the Anticancer Activities of Digitoxin MeON-Neoglycosides and O-Glycosides: Oligosaccharide Chain Length-Dependent Induction of Caspase-9-Mediated Apoptosis. ACS Medicinal Chemistry Letters 2010, 1(7):326-330.

11. Langenhan JM, Engle JM, Slevin LK, Fay LR, Lucker RW, Smith KR, Endo MM: Modifying the glycosidic linkage in digitoxin analogs provides selective cytotoxins. Bioorganic \& Medicinal Chemistry Letters 2008, 18(2):670-673.

12. Zhou M, O'Doherty G: The De novo Synthesis of Oligosaccharides Application to the Medicinal Chemistry SAR Study of Digitoxin. ChemInform 2008, 39(27):no-no. 
13. Wang $\mathrm{H}-\mathrm{YL}$, Xin $\mathrm{W}$, Zhou M, Stueckle TA, Rojanasakul $\mathrm{Y}$, O'Doherty GA: Stereochemical Survey of Digitoxin Monosaccharides. ACS Medicinal Chemistry Letters 2010, 2(1):73-78.

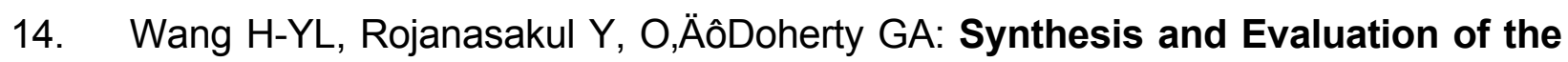
a-d-/a-I-Rhamnosyl and Amicetosyl Digitoxigenin Oligomers as Antitumor Agents. ACS Medicinal Chemistry Letters 2011, 2(4):264-269.

15. Wang H-YL, Wu B, Zhang Q, Kang S-W, Rojanasakul Y, O,ÄôDoherty GA: C5'Alkyl Substitution Effects on Digitoxigenin $\alpha-I-G l y c o s i d e$ Cancer Cytotoxicity. ACS Medicinal Chemistry Letters 2011, 2(4):259-263.

16. Mijatovic T, Op De Beeck A, Van Quaquebeke E, Dewelle J, Darro F, de Launoit Y, Kiss R: The cardenolide UNBS1450 is able to deactivate nuclear factor KBmediated cytoprotective effects in human non-small cell lung cancer cells Molecular Cancer Therapeutics 2006, 5(2):391-399.

17. Piao CQ, Liu L, Zhao YL, Balajee AS, Suzuki M, Hei TK: Immortalization of human small airway epithelial cells by ectopic expression of telomerase. Carcinogenesis 2005, 26(4):725-731.

18. Baggot JD, Davis LE: Plasma protein binding of digitoxin and digoxin in several mammalian species. Res Vet Sci 1973, 15(1):81-87.

19. Lohman JJHM, Merkus FWHM: Plasma protein binding of digitoxin and some other drugs in renal disease. Pharmacy World \&amp; Science 1987, 9(2):75-78.

20. Ashkenazi A: Directing cancer cells to self-destruct with pro-apoptotic receptor agonists. Nat Rev Drug Discov 2008, 7(12):1001-1012. 
21. Dickson MA, Schwartz GK: Development of cell-cycle inhibitors for cancer therapy. Curr Oncol 2009, 16(2):36-43.

22. Stark G, Taylor W: Control of the G2/M transition. Molecular Biotechnology 2006, 32(3):227-248.

23. Mita AC, Mita MM, Nawrocki ST, Giles FJ: Survivin: Key Regulator of Mitosis and Apoptosis and Novel Target for Cancer Therapeutics. Clinical Cancer Research 2008, 14(16):5000-5005.

24. O'Connor DS, Grossman D, Plescia J, Li F, Zhang H, Villa A, Tognin S, Marchisio PC, Altieri DC: Regulation of apoptosis at cell division by $p 34 c d c 2$ phosphorylation of survivin. Proceedings of the National Academy of Sciences 2000, 97(24):13103-13107.

25. Vermeulen K, Van Bockstaele DR, Berneman ZN: The cell cycle: a review of regulation, deregulation and therapeutic targets in cancer. Cell Proliferation 2003, 36(3):131-149.

26. Bartek J, Lukas J: Chk1 and Chk2 kinases in checkpoint control and cancer. Cancer Cell 2003, 3:421-429.

27. Zhou B-BS, Bartek J: Targeting the checkpoint kinases: chemosensitization versus chemoprotection. Nat Rev Cancer 2004, 4(3):216-225.

28. Wang Y, Ji P, Liu J, Broaddus R, Xue F, Zhang W: Centrosome-associated regulators of the G2/M checkpoint as targets for cancer therapy. Mol Cancer 2009, 8(1):8.

29. Smith TW: The fundamental mechanism of inotropic action of digitalis. Therapie 1989, 44:431-435. 
30. Perne A, Muellner MK, Steinrueck M, Craig-Mueller N, Mayerhofer J, Schwarzinger I, Sloane M, Uras IZ, Hoermann G, Nijman SMB et al: Cardiac Glycosides Induce Cell Death in Human Cells by Inhibiting General Protein Synthesis. PLoS One 2009, 4(12).

31. Allan LA, Clarke PR: Phosphorylation of Caspase-9 by CDK1/Cyclin B1 Protects Mitotic Cells against Apoptosis. Molecular Cell 2007, 26(2):301-310.

32. Yuan J, Yan R, Kramer A, Eckerdt F, Roller M, Kaufmann M, Strebhardt K: Cyclin B1 depletion inhibits proliferation and induces apoptosis in human tumor cells. Oncogene 2004, 23(34):5843-5852.

33. Kometiani P, Liu L, Askari A: Digitalis-Induced Signaling by Na+/K+-ATPase in Human Breast Cancer Cells. Mol Pharmacol 2005, 67(3):929-936.

34. Wang Z, Zheng M, Li Z, Li R, Jia L, Xiong X, Southall N, Wang S, Xia M, Austin CP et al: Cardiac Glycosides Inhibit p53 Synthesis by a Mechanism Relieved by Src or MAPK Inhibition. Cancer Research 2009, 69(16):6556-6564.

35. Abbas T, Dutta A: p21 in cancer: intricate networks and multiple activities. Nat Rev Cancer 2009, 9(6):400-414.

36. Kumar R, Gururaj AE, Barnes CJ: p21-activated kinases in cancer. Nat Rev Cancer 2006, 6(6):459-471.

37. Roninson IB: Oncogenic functions of tumour suppressor p21Waf1/Cip1/Sdi1: association with cell senescence and tumour-promoting activities of stromal fibroblasts. Cancer Letters 2002, 179(1):1-14.

38. Bartek J, Lukas J: Chk1 and Chk2 kinases in checkpoint control and cancer. Cancer Cell 2003, 3(5):421-429. 


\section{SUMMARYANDCONCLUSION}

Lung cancer cells exhibit a significant sensitivity to digitoxin and its monosaccharide analog, indicating that these compounds may be clinically beneficial for management and treatment of cancer. Digitoxin and its analog, D6-MA, exhibit a selective antineoplastic effect in NSCLC cells at therapeutic concentrations. D6-MA showed 4 to 6 times greater potency than digitoxin in inhibiting non-small cell lung cancer cells viability. Digitoxin and D6-MA do not inhibit $\mathrm{Na}^{+} / \mathrm{K}^{+} \mathrm{ATPase}$ pump at their cytotoxic concentrations, indicating that inhibiting the $\mathrm{Na}^{+} / \mathrm{K}^{+}$ATPase by digitoxin or D6-MA does not account for their anticancer activity. Thus, cardiotoxicity may no longer be a concern for these compounds, since the cardiotoxicity mechanism impinges on inhibiting the $\mathrm{Na}^{+} / \mathrm{K}^{+} \mathrm{ATPase}$ pump. Additionally, if inhibiting the $\mathrm{Na}^{+} / \mathrm{K}^{+} \mathrm{ATPase}$ pump by digitoxin and D6-MA does not account for their cytotoxicity, then manipulating the $\mathrm{Na}^{+} / \mathrm{K}^{+} \mathrm{ATPase}$ signalosome remains as the general mechanism for the cellular effects exhibited by digitoxin and D6-MA.

Digitoxin and D6-MA induced apoptosis through the mitochondrial pathway as confirmed by increased cytochrome c and caspase9 cleavage and activation. D6-MA was even more potent than digitoxin in inducing cytochrome c expression and caspase 9 activation and in inhibiting the expression of cyclin B1, cdc2, and survivin. The ability of digitoxin and D6-MA to inhibit cyclin B1, cdc2, and survivin explains the ability of the compounds to specifically activate caspase9. Additionally, down regulation of cyclin B1, cdc2, and survivin contributes to explaining the strong reduction in cell viability induced by digitoxin and D6-MA. 
Interestingly, however, the cytotoxic effect of digitoxin and D6-MA is independent of up regulation of p53 or checkpoint kinase proteins. This indicates that other signaling pathways are controlling this cytotoxic effect and so further research is required to delineate such mechanisms. Additionally, the ability of digitoxin and D6-MA to inhibit the expression of checkpoint kinase proteins further explains their potent cytotoxic activity in cancer cells. Such discoveries open up possibilities for new chemotherapeutic compounds that specifically target apoptosis in cancer cells at concentrations that are non-toxic to normal cells. 


\section{CURRICULUM VITAE}

\section{HOSAM A. ELBAZ}

Department of Basic Pharmaceutical

Sciences

West Virginia University

Morgantown, WV, 26506

helbaz@hsc.wvu.edu
1239 Pineview DR

Morgantown, WV, 26505

(304) 376-3430

haelbaz@gmail.com

\section{EDUCATION}

Ph.D. in Pharmaceutical and Pharmacological Sciences, 2011

West Virginia University

Dissertation: Characterization of the pharmacological effects of cardiac glycosides on lung epithelial cells

Chair: Cerasela Zoica Dinu, Ph.D.

Committee: Yon Rojanasakul, Ph.D., Patrick Callery, Ph.D., Rae Matsumoto, Ph.D., and Linda Vona-Davis, Ph.D.

\section{B.Pharm, 2005}

Misr International University, Heliopolis, Cairo, Egypt

Cumulative Grade Point Average (GPA): 3.79 out of 4.00 


\section{RESEARCH EXPERIENCE}

Mentors: Drs. C. Z. Dinu, and Y. Rojanasakul

Research Assistant, Department of Basic Pharmaceutical Sciences, West Virginia University, $2007-2011$.

- Examining the mechanism by which digitoxin promotes barrier functions in lung cancer cells and how this effect correlates with its anticancer effect.

- Contributed to examining the mechanism by which digitoxin and synthetic monosaccharide analogs inhibit angiogenesis, using Western blot analysis, microarray, and enzyme-linked immunosorbent assay (ELISA).

-Examined the mechanism by which digitoxin and synthetic monosaccharide analogs induce apoptosis, and inhibit cell cycle progression and cell viability in lung cancer cells.

-Maintained and utilized human lung epithelial cell lines.

-Performed cell viability assays, flow cytometry, Western blot analysis, and fluorescence staining to illustrate the cytotoxic effect of cardiac glycosides on lung cancer cells.

- Performed cytotoxicity and barrier functions studies using electric cell-substrate impedance sensing (ECIS) technology, confocal microscopy, microarray, and Western blot analysis to illustrate the effect of digitoxin on barrier functions in lung cancer cells.

- Supervised 1 graduate student. 


\section{PUBLICATIONS}

-Elbaz, H., El Dawud, R., Stueckle, T., Rojanasakul, Y., Dinu, C.Z., (in preparation). Stimulation of Barrier Function by Digitoxin Correlates with its Growth Inhibitory Activity in Lung Cancer Cells.

-Stueckle TA, Elbaz H, Lu Y, O'Doherty GA, Rojanasakul Y., (in preparation). Whole genome expression profiling of novel digitoxin analog treatment on NSCLC: novel insights into cardiac glycoside anti-cancer activity.

•Elbaz, H., Stueckle, T., Tse, W., Rojanasakul, Y., Dinu, C.Z., (Under review) Digitoxin, a cardiac glycosides with the potential to provide a new hope for cancer therapy. Experimental hematology and Oncology.

•Elbaz, H., Stueckle, T., Wang, H., O’Doherty, G., Lowery, D., Sargent, L., Wang, L., Dinu, C.Z., Rojanasakul, Y. (In press), Digitoxin and Synthetic Analog Inhibit Cell Viability in Lung Cancer Cells. Tox. And App. Pharm. DOI:10.1016/j.taap.2011.10.007 •lyer, A., Zhou, M., Azad, N., Elbaz, H., Wang, L., Rogalsky, K., Rojanasakul, Y., O'Doherty, G. \& Langenhan, J. (2010). A Direct Comparison of the Anti cancer Activities of Digitoxin MeON-Neoglycosides and O-Glycosides. ACS Medicinal Chemistry. Jul 12;1(7):326-330. PMCID: PMC2916185.

\section{ORAL PRESENTATION}

•Elbaz, H., El Dawud, R., Stueckle, T., Rojanasakul, Y., Dinu, C.Z., (10/2011) Stimulation of Barrier Function by Digitoxin. The $3^{\text {rd }}$ Annual AAPS Pittsburgh Chapters Student Research Symposium. 
•Elbaz, H., El Dawud, R., Stueckle, T., Rojanasakul, Y., Dinu, C.Z., (10/2011) Stimulation of Barrier Function by Digitoxin correlates with its growth inhibitory activity. WVU Pharmaceutical \& Pharmacological Sciences Seminar.

•Elbaz, H., Stueckle, T., Rojanasakul, Y., Dinu, C.Z., (3/2011) Effect of digitoxin on tight junction formation in Non-small cell lung cancer cells. WVU Pharmaceutical \& Pharmacological Sciences Seminar.

•Elbaz, H., Stueckle, T., O'Doherty, G., Dinu, C.Z., and Rojanasakul, Y. (9/2010) Digitoxin and a Novel Monosaccharide Analog Inhibit Cell Viability and Induce Cell Cycle Arrest in Non-small cell lung cancer cells. WVU Pharmaceutical \& Pharmacological Sciences Seminar.

-Elbaz, H., Stueckle, T., O'Doherty, G., and Rojanasakul, Y. (1/2010) Molecular effects of digitoxin on NSCLC cells. WVU Pharmaceutical \& Pharmacological Sciences Seminar.

•Elbaz, H., Stueckle, T., O'Doherty, G., and Rojanasakul, Y. (12/2009) Molecular effects of digitoxin on NSCLC cells. WVU Pharmaceutical \& Pharmacological Sciences Seminar.

-Elbaz, H., Iyer, A., O'Doherty, G., and Rojanasakul, Y. (3/2009) Digitoxin induces apoptosis in NSCLC cells ( $\mathrm{H}-460$ cells) possibly by multiple mechanisms. WVU Pharmaceutical \& Pharmacological Sciences Seminar.

-Elbaz, H., lyer, A., O'Doherty, G., and Rojanasakul, Y. (3/2009) Digitoxin and its novel derivatives induce apoptosis in Non-small cell lung cancer cells ( $\mathrm{H}-460$ cells) in the nanomolar concentrations. WVU Pharmaceutical \& Pharmacological Sciences Seminar. 


\section{POSTER PRESENTATIONS}

- Elbaz, H., El Dawud, R., Stueckle, T., Rojanasakul, Y., Dinu, C.Z., (10/2011) Stimulation of Barrier Function by Digitoxin. HSC SOP Research Day. Morgantown, WV.

-Elbaz, H., Stueckle, T., O’Doherty, G., Dinu, C.Z., and Rojanasakul, Y. (3/2011) Digitoxin and a Novel Monosaccharide Analog Inhibit Cell Viability and Induce Cell Cycle Arrest in Non-Small Cell Lung Cancer Cells. WVU HSC Research Day. Morgantown, WV.

•Elbaz, H., Stueckle, T., O’Doherty, G., Dinu, C.Z., and Rojanasakul, Y. (9/2010) Digitoxin and a Novel Monosaccharide Analog Inhibit Cell Viability and Induce Cell Cycle Arrest in Non-Small Cell Lung Cancer Cells. HSC SOP Research Day. Morgantown, WV.

-Elbaz, H., Stueckle, T., O’Doherty, G. \& Rojanasakul, Y. (4/2010). Digitoxin and a novel synthetic derivative show anti-neoplastic and cell cycle arrest activity against NSCLC cells. WVU HSC Research Day. Morgantown, WV.

-Stueckle, T., Wang, H., Pongrakhananon, V., Elbaz, H., O'Doherty, G. \& Rojanasakul, Y. (4/2010). Digitoxin Synthetic analogues: A new hope for anti-cancer therapy? WVU HSC Research Day. Morgantown, WV.

- Elbaz, H., Stueckle, T., O’Doherty, G. \& Rojanasakul, Y. (2/2010). Low dose digitoxin induces G2/M phase arrest and reduces proliferation in NSCLC cells. $\underline{\text { HSC SOP }}$ Research Day. Morgantown, WV.

-Elbaz, H., Iyer, A., Rojanasakul, Y. (11/2009). Apoptotic and Cytostatic Effects of Digitoxin in Human Lung Epithelial Cells. AAPS National Meeting. Nov. 11. Los Angeles, CA. 


\section{TEACHING EXPERIENCE}

Teaching Assistant, West Virginia University, 2010 - 2011

- Biopharmaceutical Colloquium PHAR 783

- Organized and coordinated activities and assignments

- Chemistry of Drug Action PHAR 711

- Graded exams

- Pharmaceutical Care Lab 1 PHAR 701

- Delivered 8 labs

- Proctored and graded exams

- Pharmaceutics 1 PHAR 702

- Collaborated to design exams

- Proctored and graded exams

Teaching Assistant, Misr International University, 2005-2007

- Dermatology and Cosmetics PHT417

- Delivered all labs for 200 students

- Designed in-class activities and assignments

- Proctored practical exams 
- Hospital Pharmacy 1 PHP421

- Delivered all labs for 240 students

- Enhanced coarse content by re-designing the its structure

- Designed in-class activities, case studies, and assignments

- Proctored practical exams

- Collaborated in designing pre-labs and exams

- Hospital Pharmacy 2 PHP523

- Delivered all labs for 70 students

- Designed in-class activities, case studies, and assignments

- Proctored practical exams

- Industrial Pharmacy 1 PHT522

- Delivered all labs for 240 students

- Designed in-class activities and assignments

- Proctored practical exams

- Pharmaceutical Quality Control PHT541

- Delivered all labs for 240 students

- Proctored practical exams

- Collaborated in designing pre-labs and exams

- Collaborated in grading exams 
- Pharmaceutics PHT213

- Delivered all labs for 240 students

- Proctored practical exams

- Collaborated in designing pre-labs and exams

- Collaborated in grading exams

\section{HONORS AND AWARDS}

- $\quad$ NSF Graduate Research Fellowship, 2010-2011

- By Invitation, Member of Golden Key International Honor Society, 2010

- WVU Travel Award, West Virginia University, 2009

- Graduate Research Assistantship, West Virginia University, 2007-2010

- Teaching Assistantship, Misr International University, 2005-2007

- Merit Scholarship, Misr International University, 2000-2005

\section{OTHER WORK EXPERIENCE}

-Attended and participated in "Write Winning Grants" workshop, National research Center for Coal and Energy, West Virginia University (6/2011).

-Attended and participated in the IRT meeting with the NSF reviewers, West Virginia University (3/2011).

-Attended and Participated in a 1 month workshop on Promotion and Marketing, SIFE International, Misr International University, Cairo, Egypt, 5/2005. 
- Community Pharmacy Associate, Abu Elella Pharmacy, Cairo, Egypt, 2003 - 2005.

- Quality Control Intern Analyst, Kahira Pharmaceuticals, Cairo, Egypt, 8/2004 - 9/2004.

-Attended and Participated in a 3 day workshop on Clinical Skills, Nursing Training \& Continuing Education Center, Cairo University, Egypt, 9/2003.

-Medical Sales Intern, GlaxoSmithKline, Cairo, Egypt, 7/2003 - 8/2003.

\section{LICENSURE}

Professional Pharmacy Practicing License, Ministry of Health and Population, Egypt, 2006 - Present

\section{SKILLS}

Bilingual; Fluent English and Arabic

Teaching and Presentation skills

Oral Communication Skills

Capacity and Desire for learning

Determination

Team player / Team leader

Problem Solving

Apoptosis

Cell culture

Western blot analysis
Optical microscopy

Confocal and Fluorescence Staining Spectrophotometry

Electric Cell-Substrate Impedance Sensing (ECIS)

GraphPad Prism

Image J

Drug Target Identification / Validation

Drug Discovery

Drug Delivery 
In Vitro Pharmacology

In Vitro Toxicology

Transfection
Flow Cytometry

Titration

Pharmaceutical sales

\section{PROFESSIONAL MEMBERSHIPS}

American Chemical Society (2011-Present)

Golden Key International Honor Society (2010-Present)

American Association of Pharmaceutical Scientists (2009-Present)

American Society of Pharmacology and Experimental Therapeutics (2009-Present)

Egyptian Student Association of North America (2008-Present)

Egyptian General Syndicate of Pharmacists (2006-Present) 